Review Article

\title{
Plant growth-promoting bacteria as inoculants in agricultural soils
}

\author{
Rocheli de Souza, Adriana Ambrosini and Luciane M.P. Passaglia \\ Departamento de Genética, Instituto de Biociências, Universidade Federal do Rio Grande do Sul, \\ Porto Alegre, RS, Brazil.
}

\begin{abstract}
Plant-microbe interactions in the rhizosphere are the determinants of plant health, productivity and soil fertility. Plant growth-promoting bacteria (PGPB) are bacteria that can enhance plant growth and protect plants from disease and abiotic stresses through a wide variety of mechanisms; those that establish close associations with plants, such as the endophytes, could be more successful in plant growth promotion. Several important bacterial characteristics, such as biological nitrogen fixation, phosphate solubilization, ACC deaminase activity, and production of siderophores and phytohormones, can be assessed as plant growth promotion (PGP) traits. Bacterial inoculants can contribute to increase agronomic efficiency by reducing production costs and environmental pollution, once the use of chemical fertilizers can be reduced or eliminated if the inoculants are efficient. For bacterial inoculants to obtain success in improving plant growth and productivity, several processes involved can influence the efficiency of inoculation, as for example the exudation by plant roots, the bacterial colonization in the roots, and soil health. This review presents an overview of the importance of soil-plant-microbe interactions to the development of efficient inoculants, once PGPB are extensively studied microorganisms, representing a very diverse group of easily accessible beneficial bacteria.
\end{abstract}

Keywords: nitrogen fixation, siderophore production, plant-bacteria interaction, inoculant, rhizosphere.

Received: February 20, 2015, Accepted: May 22, 2015.

\section{Introduction}

The rhizosphere can be defined as the soil region where processes mediated by microorganisms are specifically influenced by the root system (Figure 1A). This area includes the soil connected to the plant roots and often extends a few millimeters off the root surface, being an important environment for the plant and microorganism interactions (Lynch, 1990; Gray and Smith, 2005), because plant roots release a wide range of compounds involved in attracting organisms which may be beneficial, neutral or detrimental to plants (Lynch, 1990; Badri and Vivanco, 2009). The plant growth-promoting bacteria (or PGPB) belong to a beneficial and heterogeneous group of microorganisms that can be found in the rhizosphere, on the root surface or associated to it, and are capable of enhancing the growth of plants and protecting them from disease and abiotic stresses (Dimkpa et al., 2009a; Grover et al., 2011; Glick, 2012). The mechanisms by which PGPB stimulate plant growth involve the availability of nutrients originating from genetic processes, such as biological nitrogen fixation and phosphate solubilization, stress alleviation

Send correspondence to Luciane M.P. Passaglia. Departamento de Genética, Instituto de Biociências, Universidade Federal do Rio Grande do Sul, Av. Bento Gonçalves 9500, Caixa Postal 15.053, 91501-970 Porto Alegre, RS, Brazil. E-mail: luciane.passaglia@ufrgs.br. through the modulation of ACC deaminase expression, and production of phytohormones and siderophores, among several others.

Interactions between plants and bacteria occur through symbiotic, endophytic or associative processes with distinct degrees of proximity with the roots and surrounding soil (Figure 1A). Endophytic PGPB are good inoculant candidates, because they colonize roots and create a favorable environment for development and function. Non-symbiotic endophytic relationships occur within the intercellular spaces of plant tissues, which contain high levels of carbohydrates, amino acids, and inorganic nutrients (Bacon and Hinton, 2006).

Agricultural production currently depends on the large-scale use of chemical fertilizers (Wartiainen et al., 2008; Adesemoye et al., 2009). These fertilizers have become essential components of modern agriculture because they provide essential plant nutrients such as nitrogen, phosphorus and potassium. However, the overuse of fertilizers can cause unanticipated environmental impacts (Shenoy et al., 2001; Adesemoye et al., 2009). To achieve maximum benefits in terms of fertilizer savings and better growth, the PGPB-based inoculation technology should be utilized along with appropriate levels of fertilization. Moreover, the use of efficient inoculants can be considered an important strategy for sustainable management and for re- 

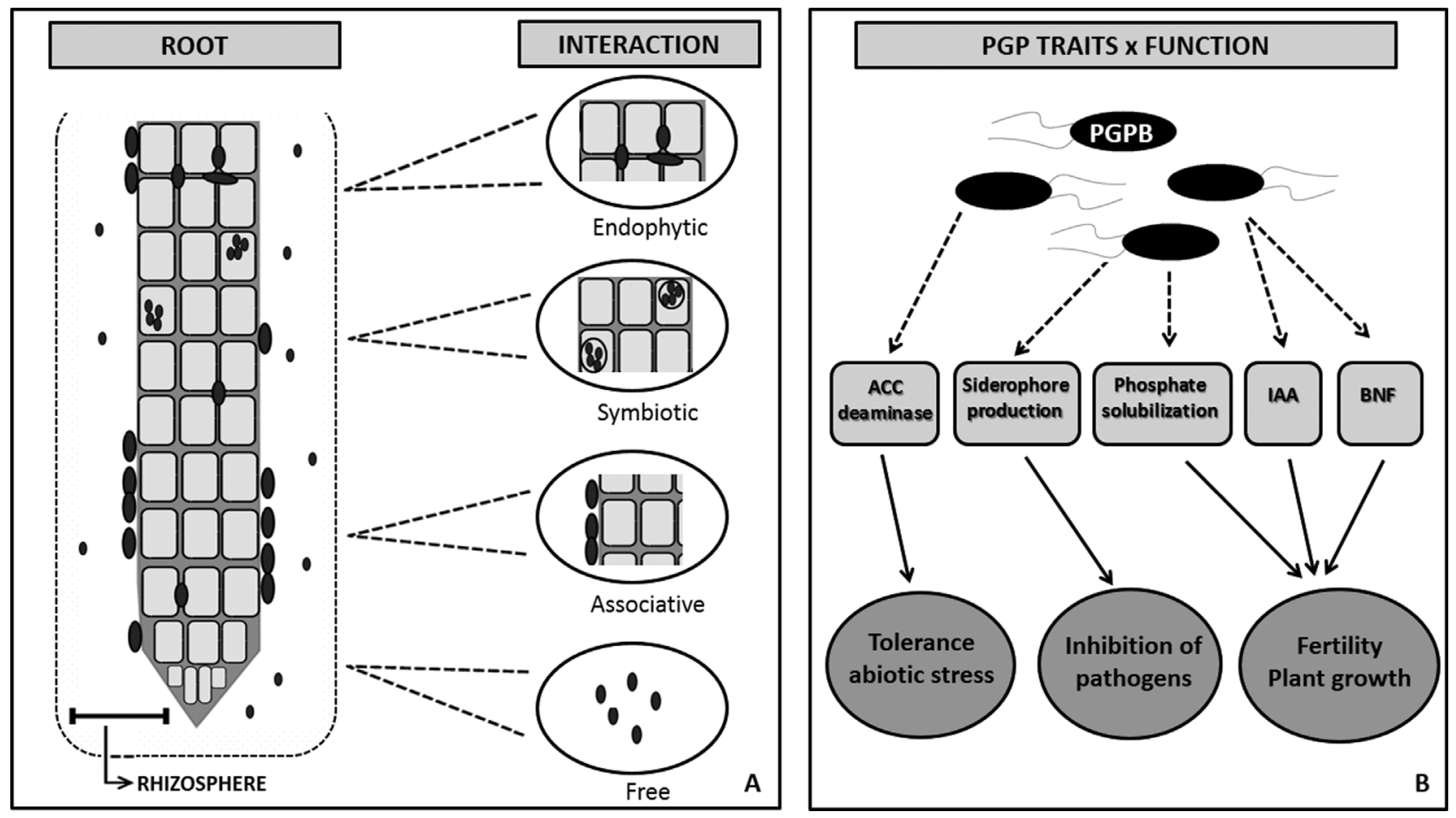

Figure 1 - Rhizosphere/bacteria interactions. A) Different types of association between plant roots and beneficial soil bacteria; B) After colonization or association with roots and/or rhizosphere, bacteria can benefit the plant by (i) tolerance toward abiotic stress through action of ACC deaminase; (ii) defense against pathogens by the presence of competitive traits such as siderophore production; (iii) increase of fertility and plant growth through biological nitrogen fixation (BNF), IAA (indole-3-acetic acid) production, and phosphate solubilization around roots.

ducing environmental problems by decreasing the use of chemical fertilizers (Alves et al., 2004; Adesemoye et al., 2009; Hungria et al., 2010, 2013).

The success and efficiency of PGPB as inoculants for agricultural crops are influenced by various factors, among which the ability of these bacteria to colonize plant roots, the exudation by plant roots and the soil health. The root colonization efficiency of PGPB is closely associated with microbial competition and survival in the soil, as well as with the modulation of the expression of several genes and cell-cell communication via quorum sensing (Danhorn and Fuqua, 2007; Meneses et al., 2011; Alquéres et al., 2013; Beauregard et al., 2013). Plant roots react to different environmental conditions through the secretion of a wide range of compounds which interfere with the plant-bacteria interaction, being considered an important factor in the efficiency of the inoculants (Bais et al., 2006; Cai et al., 2009, 2012; Carvalhais et al., 2013). Soil health is another important factor that affects the inoculation efficiency, due to several characteristics such as soil type, nutrient pool and toxic metal concentrations, soil moisture, microbial diversity, and soil disturbances caused by management practices.

\section{Mechanisms of Plant Growth Promotion}

The mechanisms by which bacteria can influence plant growth differ among species and strains, so typically there is no single mechanism for promoting plant growth. Studies have been conducted regarding the abilities of various bacteria to promote plant growth, among them the endophytic bacteria. Endophytes are conventionally defined as bacteria or fungi that colonize internal plant tissues, can be isolated from the plant after surface disinfection and cause no negative effects on plant growth (Gaiero et al., 2013). Many bacteria promote plant growth at various stages of the host plant life cycle through different mechanisms (Figure 1B). Here we discuss five important mechanisms of PGPB.

\section{Biological nitrogen fixation}

All organisms require nitrogen $(\mathrm{N})$ to synthesize biomolecules such as proteins and nucleic acids. However, the main source of $\mathrm{N}$ in nature, the atmospheric nitrogen $\left(\mathrm{N}_{2}\right)$, is not accessible to most living organisms, including eukaryotes. Biological nitrogen fixation (BNF) is the process responsible for the reduction of $\mathrm{N}_{2}$ to ammonia $\left(\mathrm{NH}_{3}\right)$ (Newton, 2000; Franche et al., 2009) and is performed in diazotrophic microorganisms, particularly bacteria and archaea (Dixon and Kahn, 2004).

Diazotrophic microorganisms perform BNF through nitrogenase, a highly conserved enzyme that comprises two metalloproteins, FeMo-protein and Fe-protein (Dixon and Kahn, 2004). Although there are many morphological, physiological and genetic differences between the diazo- 
trophics, as well as an enormous variability of environments where they can be found, they all contain the enzyme nitrogenase (Moat and Foster, 1995; Boucher et al., 2003; Zehr et al., 2003; Dixon and Kahn, 2004). Klebsiella oxytoca M5a1 was the first diazotrophic bacterium that had the genes involved in the synthesis and functioning of nitrogenase (nif, $\mathrm{N}_{2}$ fixation) identified and characterized. In the genome of this bacterium, 20 nif genes are grouped in a 24-kb chromosomal region, organized into 8 operons: nifJ, nifHDKTY, nifENX, nifUSVWZ, nifM, nifF, nifLA, and nifBQ (Arnold et al., 1988). The nifD and nifK genes encode the FeMo-protein, and nifH encodes the Fe-protein (Boucher et al., 2003).

Among the leguminous plants of the Fabaceae family, the soil bacteria of the Rhizobiaceae (rhizobia) family are confined to the root nodules (Willems, 2007). Within these nodules, rhizobia effectively perform BNF through the adequate control of the presence of oxygen, an inhibitor of nitrogenase activity (Dixon and Kahn, 2004; Shridhar, 2012). Many species of microorganisms are used in the cultivation of plants of economic interest, facilitating the host plant growth without the use of nitrogenous fertilizers. For instance, the production of soybean (Glycine $\max \mathrm{L}$.) in Brazil is an excellent example of the efficiency of BNF through the use of different strains of Bradyrhizobium sp., such as B. japonicum and B. elkanii (Alves et al., 2004; Torres et al., 2012). The importance of endophytic $\mathrm{N}_{2}$-fixing bacteria has also been the object of studies in nonleguminous plants such as sugarcane (Saccharum officinarum L.; Thaweenut et al., 2011). Other studies have suggested that bradyrhizobia colonize and express nifH not only in the root nodules of leguminous plants but also in the roots of sweet potatoes (Ipomoea batatas L.), acting as diazotrophic endophytes (Terakado-Tonooka et al., 2008).

Herbaspirillum sp. is a gram-negative bacterium associated with important agricultural crops, such as rice (Oryza sativa L.; Pedrosa et al., 2011; Souza et al., 2013), sorghum (Sorghum bicolor L.; James et al., 1997), maize (Zea mays L.; Monteiro et al., 2008), and sugarcane (Pedrosa et al., 2011). Fluorescence and electron microscopy have revealed that the Herbaspirillum sp. strain B501 colonizes the intercellular spaces of wild rice (Oryza officinalis) leaves, fixing $\mathrm{N}_{2}$ in vivo (Elbeltagy et al., 2001), and expresses nif genes in wild rice shoots (You et al., 2005). This same strain also colonizes the intercellular spaces of the roots and stem tissues of sugarcane plants, showing non-specificity to the host plant (Njoloma et al., 2006). Inoculations of barley (Hordeum vulgare L.) and Miscanthus plants with a strain of $H$. frisingense showed that this bacterium is a true plant endophyte (Rothballer et al., 2008).

The PGPB related to genus Azospirillum have been largely studied because of their efficiency in promoting the growth of different plants of agronomical interest. Garcia de Salamone et al. (1996) showed that Azospirillum sp. contribute to plant fitness through BNF. The genus
Burkholderia also includes species that fix $\mathrm{N}_{2} . B$. vietnamiensis, a human pathogenic species, was efficient in colonizing rice roots and fixing $\mathrm{N}_{2}$ (Govindarajan et al., 2008). In addition to Burkholderia, the potential of BNF and endophytic colonization of bacteria belonging to the genera Pantoea, Bacillus and Klebsiella was also confirmed in different maize genotypes (Ikeda et al., 2013). Gluconacetobacter diazotrophicus is another well-studied endophyte (Baldani et al., 1997; Oliveira et al., 2002; Muthukumarasamy et al., 2005; Bertalan et al., 2009). In conditions of $\mathrm{N}$ deficiency, the G. diazotrophicus strain Pal5 isolated from sugarcane is able to increase the $\mathrm{N}$ content when compared with plants inoculated with a Nif mutant or uninoculated plants (Sevilla et al., 2001).

\section{Production of indolic compounds}

The influence of bacteria in the rhizosphere of plants is largely due to the production of auxin phytohormones (Spaepen et al., 2007). Several bacterial species can produce indolic compounds (ICs) such as the auxin phytohormone indole-3-acetic acid (IAA), which present great physiological relevance for bacteria-plant interactions, varying from pathogenesis to phytostimulation (Spaepen et al., 2007). The ability to produce ICs is widely distributed among plant-associated bacteria. Souza et al. (2013) demonstrated that approximately $80 \%$ of bacteria isolated from the rhizosphere of rice produce ICs. Other studies have shown that rhizosphere bacteria produce more ICs than bulk soil bacteria (Khalid et al., 2004), and in a recent study Costa et al. (2014) showed that this effect was also observed in endophytic bacteria, demonstrating high IC production in the Enterobacteriaceae family (Enterobacter, Escherichia, Grimontella, Klebsiella, Pantoea, and Rahnella).

The synthesis of ICs in bacteria depends on the presence of precursors in root exudates. Among the various exudates, L-tryptophan has been identified as the main precursor for the route of IC biosynthesis in bacteria. The characterization of intermediate compounds has led to the identification of different pathways that use L-tryptophan as the main precursor. The different pathways of IAA synthesis in bacteria show a high degree of similarity with the IAA biosynthesis pathways in plants (Spaepen et al., 2007). Beneficial bacteria predominantly synthesize IAA via the indole-3-pyruvic acid pathway, an alternative pathway dependent on L-tryptophan. In phytopathogenic bacteria, IAA is produced from L-tryptophan via the indol-acetoamide pathway. In $A$. brasilense, at least three biosynthesis pathways have been described for the production of IAA: two L-tryptophan-dependent (indole-3-pyruvic acid and indole-acetoamide pathways) and one L-tryptophan-independent (Prinsen et al., 1993), with the indole-3-pyruvic acid pathway as the most important among them (Spaepen et al., 2008). 
The potential of rhizobia to establish symbiosis with legumes has been well documented; however, studies have indicated the importance of IAA in nodulation events. The co-inoculation of beans (Phaseolus vulgaris L.; cultivar DOR364) with A. brasilense Sp245 and Rhizobium etli CNPAF512 yielded a greater number of nodules; however, the results obtained using a mutant strain of Azospirillum that produced only $10 \%$ of the IAA of the wild-type strain were not satisfactory, indicating the importance of bacterial IAA in the establishment and efficiency of symbiosis (Remans et al., 2008). IAA-producing Azospirillum sp. also promoted alterations in the growth and development of wheat (Triticum aestivum L.) plants (Dobbelaere et al., 1999; Akbari et al., 2007; Spaepen et al., 2008; Baudoin et al., 2010).

Soil microorganisms are capable of synthesizing and catabolizing IAA. The capacity of catabolizing IAA has been well characterized in B. japonicum (Jensen et al., 1995) and Pseudomonas putida 1290 (Leveau and Lindow, 2005). P. putida 1290 uses IAA as the sole source of carbon $(C)$, nitrogen $(N)$, and energy. In addition to the utilization of IAA, strain 1290 also produced IAA in culture medium supplemented with L-tryptophan. In co-inoculation experiments in radish (Raphanus sativus $\mathrm{L}$.) roots, this strain minimized the negative effects of high IAA concentrations produced by the pathogenic bacteria Rahnella aquaticus and $P$. syringae. In this context, microorganisms that catabolize IAA might also positively affect the growth of plants and prevent pathogen attack (Leveau and Lindow, 2005).

\section{Siderophore production}

Iron $(\mathrm{Fe})$ is an essential micronutrient for plants and microorganisms, as it is involved in various important biological processes, such as photosynthesis, respiration, chlorophyll biosynthesis (Kobayashi and Nishizawa, 2012), and BNF (Dixon and Kahn, 2004). In anaerobic and acidic soils, such as flooded soils, high concentrations of ferrous $\left(\mathrm{Fe}^{2+}\right)$ ions generated through the reduction of ferric $\left(\mathrm{Fe}^{+}\right)$ ions might lead to iron toxicity due to excessive Fe uptake (Stein et al., 2009). Under aerobic conditions, iron solubility is low, reflecting the predominance of $\mathrm{Fe}^{3+}$ typically observed as oxyhydroxide polymers, thereby limiting the $\mathrm{Fe}$ supply for different forms of life, particularly in calcareous soils (Andrews et al., 2003; Lemanceau et al., 2009). Microorganisms have developed active strategies for Fe uptake. Bacteria can overcome the nutritional Fe limitation by using chelator agents called siderophores. Siderophores are defined as low-molecular-mass molecules $(<1000 \mathrm{Da})$ with high specificity and affinity for chelating or binding $\mathrm{Fe}^{3+}$, followed by the transportation and deposition of $\mathrm{Fe}$ within bacterial cells (Neilands, 1995; Krewulak and Vogel, 2008).

Various studies have shown that siderophores are largely produced by bacterial strains associated with plants. This characteristic was the most common trait found in iso- lates associated with sunflower (Helianthus annuиs L.; Ambrosini et al., 2012) and rice (Souza et al., 2013). Notably, in rice roots, isolates belonging to genera Enterobacter and Burkholderia produced the highest levels of siderophores (Souza et al., 2013, 2014). Costa et al. (2014) simultaneously analyzed the PGPB datasets from seven independent studies that employed similar methodologies for bioprospection and observed that $64 \%$ of all isolates and $100 \%$ of all bacterial genera presented siderophoreproducing strains. The bacterial genera Burkholderia, Enterobacter and Grimontella presented strains with high siderophore production, while the genera Klebsiella, Stenotrophomonas, Rhizobium, Herbaspirillum and Citrobacter presented strains with low siderophore production.

The excretion of siderophores by bacteria might stimulate plant growth, thereby improving nutrition (direct effect) or inhibiting the establishment of phytopathogens (indirect effect) through the sequestration of $\mathrm{Fe}$ from the environment. Unlike microbial pathogens, plants are not affected by bacterial-mediated $\mathrm{Fe}$ depletion, and some plants can even capture and utilize $\mathrm{Fe}^{3+}$-siderophore bacterial complexes (Dimkpa et al., 2009b). The role of endophytic siderophore-producing bacteria has been rarely studied; however, the ability to produce siderophores confers competitive advantages to endophytic bacteria for the colonization of plant tissues and the exclusion of other microorganisms from the same ecological niche (Loaces et al., 2011). These authors observed that the community of endophytic siderophore-producing bacteria associated to rice roots is richer than those from the soil at the tillering and grain-filling stages. Endophytic bacterial strains belonging to genus Burkholderia showed preferential localization inside rice plants, and their role may be relevant to prevent the infection of young plants by Sclerotium oryzae and Rhizoctonia oryzae.

In maize, endophytic strains belonging to genus $B a-$ cillus show different plant growth-promoting characteristics, such as siderophore production, and these effects were the most efficient against the growth of Fusarium verticillioides, Colletotrichum graminicola, Bipolaris maydis, and Cercospora zea-maydis fungi (SzilagyiZecchin et al., 2014). Siderophores produced by $A$. brasilense (REC2, REC3) showed in vitro antifungal activity against Colletotrichum acutatum (the causal agent of anthracnose). Also, a reduction of disease symptoms was observed in strawberry (Fragaria vesca) plants previously inoculated with $A$. brasilense (Tortora et al., 2011).

\section{ACC deaminase activity}

Ethylene is an endogenously produced gaseous phytohormone that acts at low concentrations, participating in the regulation of all processes of plant growth, development and senescence (Shaharoona et al., 2006; Saleem et al., 2007). In addition to acting as a plant growth regulator, 
ethylene has also been identified as a stress phytohormone. Under abiotic and biotic stresses (including pathogen damage, flooding, drought, salt, and organic and inorganic contaminants), endogenous ethylene production is substantially accelerated and adversely affects the growth of the roots and thus the growth of the plant as a whole.

A number of mechanisms have been investigated aiming to reduce the levels of ethylene in plants. One of these mechanisms involves the activity of the bacterial enzyme 1-aminocyclopropane-1-carboxylate (ACC) deaminase (Glick, 2005; Jalili et al., 2009; Farajzadeh et al., 2012). ACC deaminase regulates the production of plant ethylene by metabolizing ACC (the immediate precursor of ethylene biosynthesis in higher plants) into $\alpha$-ketobutyric acid and ammonia (Arshad et al., 2007; Saleem et al., 2007). A significant amount of plant ACC might be excreted from the plant roots and subsequently taken up by soil microorganisms and hydrolyzed by the enzyme ACC deaminase, thus decreasing the amount of ACC in the environment. When associated with plant roots, soil microbial communities with ACC deaminase activity might have a better growth than other free microorganisms, as these organisms use ACC as a source of nitrogen (Glick, 2005).

Bacterial ACC deaminase activity can be conceptually divided into two groups, based on high or low enzymatic activity (Glick, 2005). High ACC deaminaseexpressing microorganisms nonspecifically bind to a variety of plant surfaces, and these microbes include rhizosphere and phyllosphere microorganisms and endophytes. However, low ACC deaminase-expressing microorganisms only bind to specific plants or are only present in certain tissues, and although these microbes do not lower the overall level of ethylene produced by the plant, they might prevent a localized increase in ethylene levels. Low ACC deaminase-expressing microorganisms include most, if not all, rhizobia species (Glick, 2005). Shaharoona et al. (2006) demonstrated that the co-inoculation of mung bean (Vigna radiate L.) with Bradyrhizobium and one bacterial strain presenting ACC deaminase activity enhanced nodulation as compared to inoculation with Bradyrhizobium alone, suggesting that this approach might be effective to achieve legume nodulation.

Onofre-Lemus et al. (2009) observed that ACC deaminase activity is a widespread feature in species belonging to genus Burkholderia. These authors identified 18 species of this genus exhibiting this activity; among these bacteria, $B$. unamae was able to endophytically colonize tomato (Solanum lycopersicum L.). In addition, tomato plants inoculated with the wild-type B. unamae strain presented better growth than those inoculated with a mutant strain deficient for ACC deaminase activity (Onofre-Lemus et al., 2009). In another study, a mutation in the ACC deaminase pathway altered the physiology of the endophytic $B$. phytofirmans PsJN2 strain, including the loss of ACC deaminase activity, an increase in IAA synthesis, a de- crease in the production of siderophores and the loss of the ability to promote the growth of canola roots (Brassica napus L.; Sun et al., 2009).

Plant growth and productivity is negatively affected by abiotic stresses. Bal et al. (2013) demonstrated the effectiveness of bacteria exhibiting ACC deaminase activity, such as Alcaligenes sp., Bacillus sp., and Ochrobactrum sp., in inducing salt tolerance and consequently improving the growth of rice plants under salt stress conditions. Arshad et al. (2008) obtained similar results, demonstrating that a strain of Pseudomonas spp. with ACC deaminase activity partially eliminated the effect of drought stress on the growth of peas (Pisum sativum L.). Similarly, tomato plants pretreated with the endophytic bacteria P. fluorescens and $P$. migulae displaying ACC deaminase activity were healthier and showed better growth under high salinity stress compared with plants pretreated with an ACC deaminase-deficient mutant or without bacterial treatment (Ali et al., 2014). Moreover, the selection of endophytes with ACC deaminase activity could also be a useful approach for developing a successful phytoremediation strategy, given the potential of these bacteria to reduce plant stress (Glick, 2010).

\section{Phosphate solubilization}

Phosphorus (P) is an essential nutrient for plants, participating as a structural component of nucleic acids, phospholipids and adenosine triphosphate (ATP), as a key element of metabolic and biochemical pathways, important particularly for BNF and photosynthesis (Khan et al., 2009; Richardson and Simpson, 2011). Plants absorb P in two soluble forms: the monobasic $\left(\mathrm{H}_{2} \mathrm{PO}_{4}^{-}\right)$and the dibasic $\left(\mathrm{HPO}_{4}{ }^{2-}\right)$ (Glass, 1989). However, a large proportion of $\mathrm{P}$ is present in insoluble forms and is consequently not available for plant nutrition. Low levels of $\mathrm{P}$ reflect the high reactivity of phosphate with other soluble components (Khan et al., 2009), such as aluminum in acid soils $(\mathrm{pH}<5)$ and calcium in alkaline soils $(\mathrm{pH}>7)$ (Holford, 1997; McLaughlin et al., 2011). Organic (incorporated into biomass or soil organic matter) and inorganic compounds, primarily in the form of insoluble mineral complexes, are major sources of available $\mathrm{P}$ in the soil (Rodríguez et al., 2006; Richardson and Simpson, 2011). Therefore, the availability of P depends on the solubility of this element, which could be influenced by the activity of plant roots and microorganisms in the soil. Phosphate-solubilizing bacteria and fungi constitute approximately $1-50 \%$ and $0.1-0.5 \%$, respectively, of the total population of cultivable microorganisms in the soil (Chabot et al., 1993; Khan et al., 2009).

Among the different sources of $\mathrm{P}$ in the soil (as previously mentioned), the solubilization of inorganic phosphates has been the main focus of research studies. Phosphate-solubilizing bacteria solubilize inorganic soil phosphates, such as $\mathrm{Ca}_{3}\left(\mathrm{PO}_{4}\right)_{2}, \mathrm{FePO}_{4}$, and $\mathrm{AlPO}_{4}$, through the production of organic acids, siderophores, and hydroxyl 
ions (Jones, 1998; Chen et al., 2006; Rodríguez et al., 2006, Sharma et al., 2013). Some bacteria only solubilize calcium phosphate, while other microorganisms are capable of solubilizing other forms of inorganic phosphates at different intensities. Bacterial isolates belonging to genera Enterobacter, Pantoea and Klebsiella solubilize $\mathrm{Ca}_{3}\left(\mathrm{PO}_{4}\right)_{2}$ to a greater extent than $\mathrm{FePO}_{4}$ and $\mathrm{AlPO}_{4}$ (Chung et al., 2005). The production of organic acids, particularly gluconic and carboxylic, is one of the well-studied mechanisms utilized by microorganisms to solubilize inorganic phosphates (Rodriguez and Fraga, 1999).

Several phosphate-solubilizing bacteria have been isolated from the roots and rhizospheric soil of various plants (Ambrosini et al., 2012; Farina et al., 2012; Costa et al., 2013; Souza et al., 2013, 2014; Granada et al., 2013). Among the 336 strains associated with rice plants, Souza et al. (2013) identified 101 isolates belonging to the genera Burkholderia, Cedecea, Cronobacter, Enterobacter, Pantoea and Pseudomonas which were able to solubilize tricalcium phosphate $\left[\mathrm{Ca}_{3}\left(\mathrm{PO}_{4}\right)_{2}\right]$. Ambrosini et al. (2012) demonstrated that Burkholderia strains associated with sunflower plants were predominant in $\mathrm{Ca}_{3}\left(\mathrm{PO}_{4}\right)_{2}$ solubilization. Chen et al. (2006) had previously reported several phosphate-solubilizing bacteria strains belonging to the genera Bacillus, Rhodococcus, Arthrobacter, Serratia, Chryseobacterium, Gordonia, Phyllobacterium and Delftia. These authors also identified various types of organic acids produced by bacterial strains, such as the citric, gluconic, lactic, succinic and propionic acids.

Qin et al. (2011) suggested that the ability of rhizobia to solubilize inorganic phosphate is associated with rhizosphere acidification. Moreover, the inoculation with Rhizobium enhanced $\mathrm{P}$ acquisition by soybean plants, particularly where $\mathrm{Ca}_{3}\left(\mathrm{PO}_{4}\right)_{2}$ was the primary $\mathrm{P}$ source. The inoculation of rice with the phosphate-solubilizing diazotrophic endophytes Herbaspirillum and Burkholderia increased grain yield and nutrient uptake in plants cultivated in soil with $\mathrm{Ca}_{3}\left(\mathrm{PO}_{4}\right)_{2}$ and ${ }^{15} \mathrm{~N}$-labeled fertilizer, suggesting that the selection and use of P-solubilizing diazotrophic bacteria is an effective strategy for the promotion of P solubilization (Estrada et al., 2013).

Several studies have reported the isolation of phosphate-solubilizing bacteria from soils or rhizospheres. Confirming that endophytes are important for phosphate solubilization, Chen et al. (2014) observed that the endophyte Pantoea dispersa, isolated from the roots of cassava (Manihot esculenta C.), effectively dissolved $\mathrm{Ca}_{3}\left(\mathrm{PO}_{4}\right)_{2}$, $\mathrm{FePO}_{4}$, and $\mathrm{AlPO}_{4}$, producing salicylate, benzene-acetic and other organic acids. Moreover, the inoculation of $P$. dispersa in soil enhanced the concentration of soluble $\mathrm{P}$ in a microbial population, increasing the soil microbial diversity, which suggests that an endophyte could adapt to the soil environment and promote the release of $\mathrm{P}$.

Soil also contains a wide range of organic substrates which can be a source of phosphorus for plant growth. Or- ganic $\mathrm{P}$ forms, particularly phytates, are predominant in most soils (10-50\% of total $\mathrm{P}$ ) and mineralized by phytases (myo-inositol hexakisphosphate phosphohydrolases) (Rodríguez et al., 2006; Richardson and Simpson, 2011). Bacteria with phytase activity have been isolated from rhizosphere and proposed as PGPB to be used in soils with high content of organic P. Bacterial isolates identified as Advenella are positive for phytase production, and increased the P content and growth of Indian mustard (Brassica juncea) (Singh et al., 2014). In another study, Kumar et al. (2013) reported phytase-producing bacteria belonging to genera Tetrathiobacter and Bacillus which also promoted the growth of Indian mustard and significantly increased the $\mathrm{P}$ content. Idriss et al. (2002) reported that extracellular phytase from B. amyloliquefaciens FZB45 promoted the growth of maize seedlings. The production of phytase has been characterized in other rhizosphere bacteria, as for example, Bacillus sp., Cellulosimicrobium sp., Acetobacter sp., Klebsiella terrigena, Pseudomonas sp., Paenibacillus sp., and Enterobacter sp. (Yoon et al., 1996; Kerovuo et al., 1998; Idriss et al., 2002; Gulati et al., 2007; Acuña et al., 2011; Jorquera et al., 2011; Kumar et al., 2013; Singh et al., 2014). Moreover, bacteria with both activities, production of organic acids to solubilize inorganic $\mathrm{P}$ and production of phytase to mineralize phytate, have been isolated from the rhizospheres of different plants, such as perennial ryegrass (Lolium perenne L.), white clover (Trifolium repens $\mathrm{L}$.), wheat, oat (Avena sativa $\mathrm{L}$.) and yellow lupin (Lupinus luteus L.) (Jorquera et al., 2008).

\section{Inoculants Can Reduce Chemical Fertilization}

The demand for chemical fertilizers in agriculture has historically been influenced by interrelated factors such as population growth worldwide, economic growth, agricultural production, among others (Morel et al., 2012). Interest in the use of inoculants containing PGPB that promote plant growth and yield has increased because nitrogen fertilizers are expensive and can damage the environment through water contamination with nitrates, acidification of soils and greenhouse-gas emissions (Adesemoye et al., 2009; Hungria et al., 2013). Plant-microorganism associations have long been studied, but their exploitation in agriculture for partially or fully replacing nitrogen fertilizers is still low (Hungria et al., 2013). Moreover, plants can only use a small amount of phosphate from chemical sources, because $75-90 \%$ of the added $\mathrm{P}$ is precipitated through metal-cation complexes and rapidly becomes fixed in soils (Sharma et al., 2013). Approximately 42 million tons of nitrogenous fertilizers are applied annually on a global scale for the production of the three major crop cereals: wheat, rice, and maize. Annually, $8 \times 10^{10} \mathrm{~kg}$ of $\mathrm{NH}_{3}$ are produced by nitrogenous fertilizer industries, while $2.5 \times 10^{11} \mathrm{~kg}$ of $\mathrm{NH}_{3}$ are fixed through BNF (Cheng, 2008). The nitrogen provided by $\mathrm{BNF}$ is less prone to leaching, volatilization and denitrification, as this chemical is used in situ and is 
therefore considered an important biological process that contributes to sustainable agriculture (Dixon and Kahn, 2004).

The management of bacteria, soil and plant interactions has emerged as a powerful tool in view of the biotechnological potential of these interactions, evidenced by increased crop productivity, reduction of production costs by reducing the volume of fertilizers applied and a better conservation of environmental resources. Moreover, inoculants are composed of beneficial bacteria that can help the plant meet its demands for nutrients. As previously discussed, these bacteria increase plant growth, accelerate seed germination, improve seedling emergence in response to external stress factors, protect plants from disease, and promote root growth using different strategies (Table 1). Whether gram-negative or gram-positive, these bacteria require isolation in culture media and analysis of various genotypic and phenotypic aspects, as well as analysis regarding their beneficial interaction with the host plant in experimental and natural conditions.

Rhizobia species are well investigated because of their symbiotic relationship with leguminous plants and their agronomical application as inoculants in the cultivation of economic crops (Alves et al., 2004; Torres et al., 2012). The soybean-Bradyrhizobium association is a good example of the efficiency of BNF, and B. elkanii and $B$. japonicum are species commonly used to inoculate this leguminous plant. In this system, the BNF is so efficient that attempts to increase grain yields by adding nitrogenous fertilizers are not successful in plants effectively inoculated with the recommended Bradyrhizobium strains (Alves et al., 2004). In Brazil, where approximately $70 \%$ of the nitrogenous fertilizers are imported, the costs of mineral $\mathrm{N}$ utilization in agriculture are high, and inoculants are a more cost-effective alternative, particularly for soybean crops. It is estimated that, in this culture alone, Brazil saves approximately US\$ 7 billion per year thanks to the benefits of BNF (Hungria et al., 2013).

In the last few decades, a large array of bacteria associated with non-leguminous plants, including Azospirillum species, have demonstrated plant growth-promoting properties (Okon and Labandrera-Gonzalez, 1994; Garcia de Salamone et al., 1996; Bashan et al., 2004; Cassán and Garcia de Salamone, 2008; Hungria et al., 2010). Azospirillum might promote the growth, yield and nutrient uptake of different plant species of agronomic importance, particularly wheat and maize (Hungria et al., 2010). Inoculants containing Azospirillum have been tested under field conditions in Argentina, with positive results regarding plant growth and/or grain yield (Cassán and Garcia de Salamone, 2008). In Brazil, field experiments designed to evaluate the performance of $A$. brasilense strains isolated from maize plants showed effectiveness in both maize and wheat. These results were grounds for the authorization of the first strains of inoculants to be produced and commercially used in wheat and maize in this country. According to the authors (Hungria et al., 2010), the partial (50\%) replacement of the nitrogenous fertilizer required for these crops in association with Azospirillum sp. inoculation would save an estimated US\$ 1.2 billion per year, suggesting that the use of inoculants could reduce the use of chemical fertilizers worldwide.

Inoculation with a consortium of several bacterial strains could be an alternative to inoculation with individual strains, likely reflecting the different mechanisms used by each strain in the consortium. The co-inoculation of soybean and common bean (P. vulgaris L.) with rhizobia and A. brasilense inoculants showed good results for improving sustainability (Hungria et al., 2013). In field trials, the co-inoculation of soybean with $B$. japonicum and $A$. brasilense species resulted in outstanding increases in grain yield and improved nodulation compared with the non-inoculated control. For common bean, co-inoculation with Rhizobium tropici and $A$. brasilense species resulted in an impressive increase in grain yield, varying from $8.3 \%$ when $R$. tropici was inoculated alone to $19.6 \%$ when the two bacterial species were used. Domenech et al. (2006) showed that the inoculation of tomato and pepper with a product based on Bacillus subtilis GB03 (a growth-promoting agent), B. amyloliquefaciens IN937a (endophytic bacteria, systemic resistance inducer) and chitosan, combined with different bacterial strains such as $P$. fluorescens, provided better biocontrol against Fusarium wilt and Rhizoctonia damping-off as compared to the use of the product alone.

\section{Processes Involved in the Efficiency of Inoculation}

\section{Exudation by plant roots}

Plant roots respond to environmental conditions through the secretion of a wide range of compounds, according to nutritional status and soil conditions (Cai et al., 2012; Carvalhais et al., 2013). This action interferes with the plant-bacteria interaction and is an important factor contributing to the efficiency of the inoculant (Cai et al., 2009, 2012; Carvalhais et al., 2013). Root exudation includes the secretion of ions, free oxygen and water, enzymes, mucilage, and a diverse array of C-containing primary and secondary metabolites (Bais et al., 2006). The roots of plants excrete $10-44 \%$ of photosynthetically fixed $\mathrm{C}$, which serves as energy source, signaling molecules or antimicrobials for soil microorganisms (Guttman et al., 2014). The root exudation varies with plant age and genotype, and consequently specific microorganisms respond and interact with different host plants (Bergsma-Vlami et al., 2005; Aira et al., 2010; Ramachandran et al., 2011). Thus, inoculants are generally destined to the one specific plant from which the bacterium was isolated. 


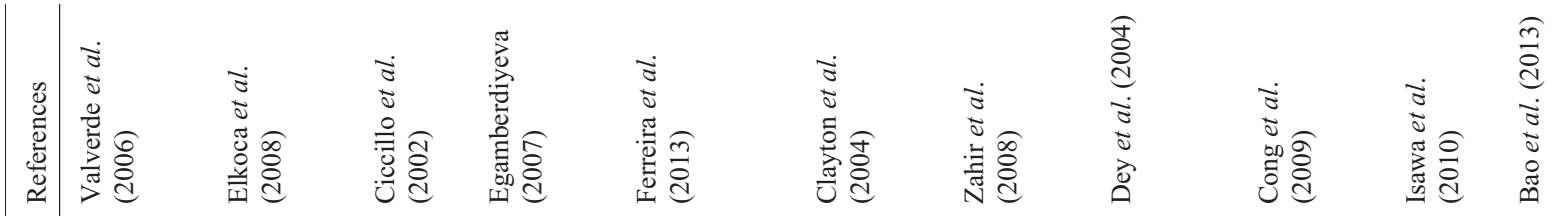

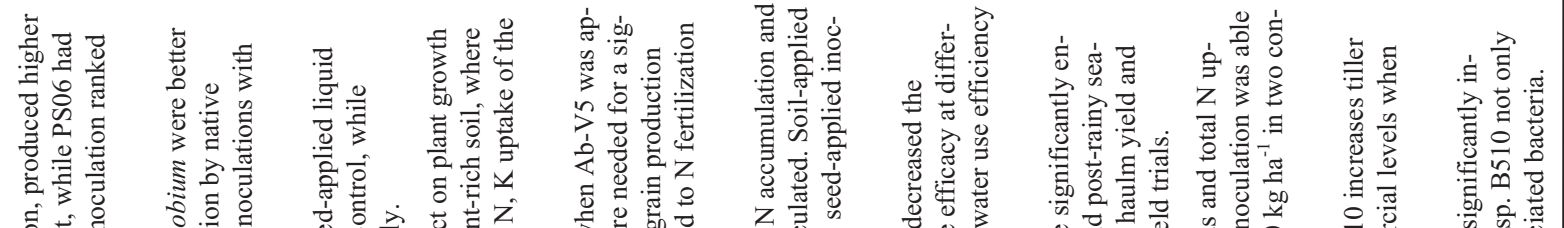

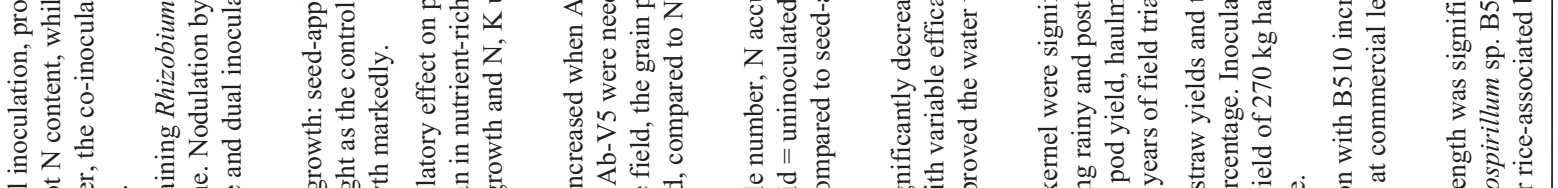

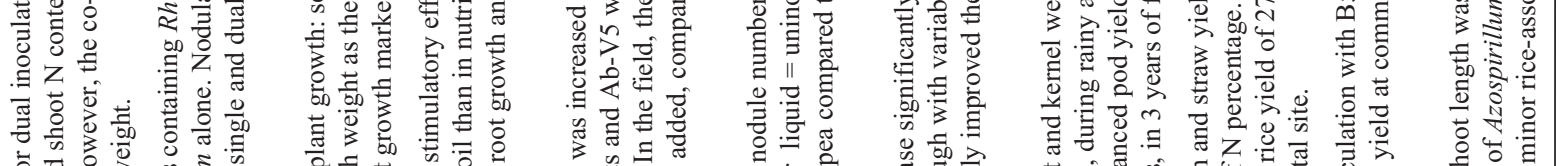

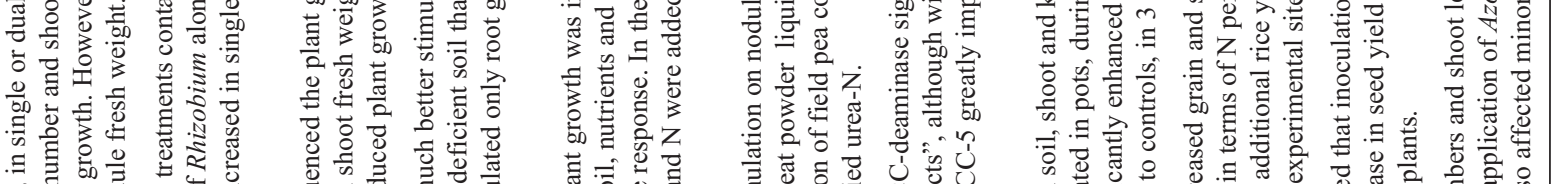

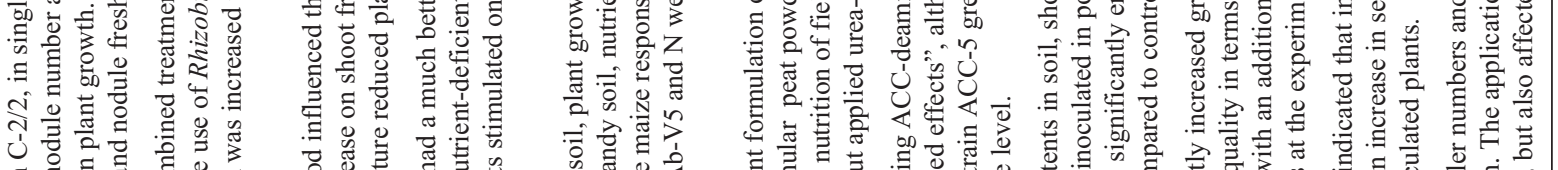

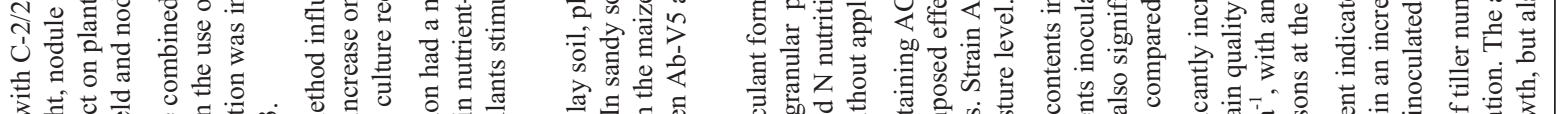

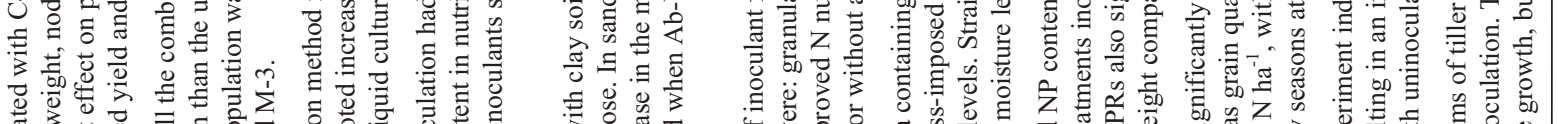

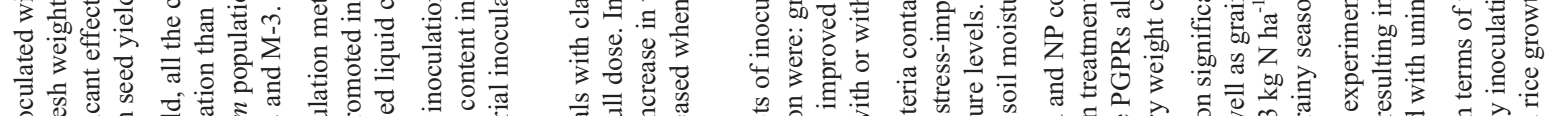

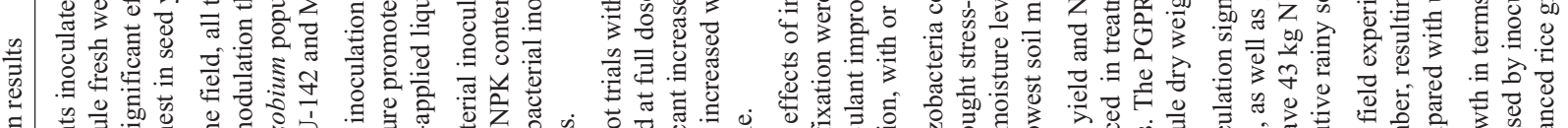
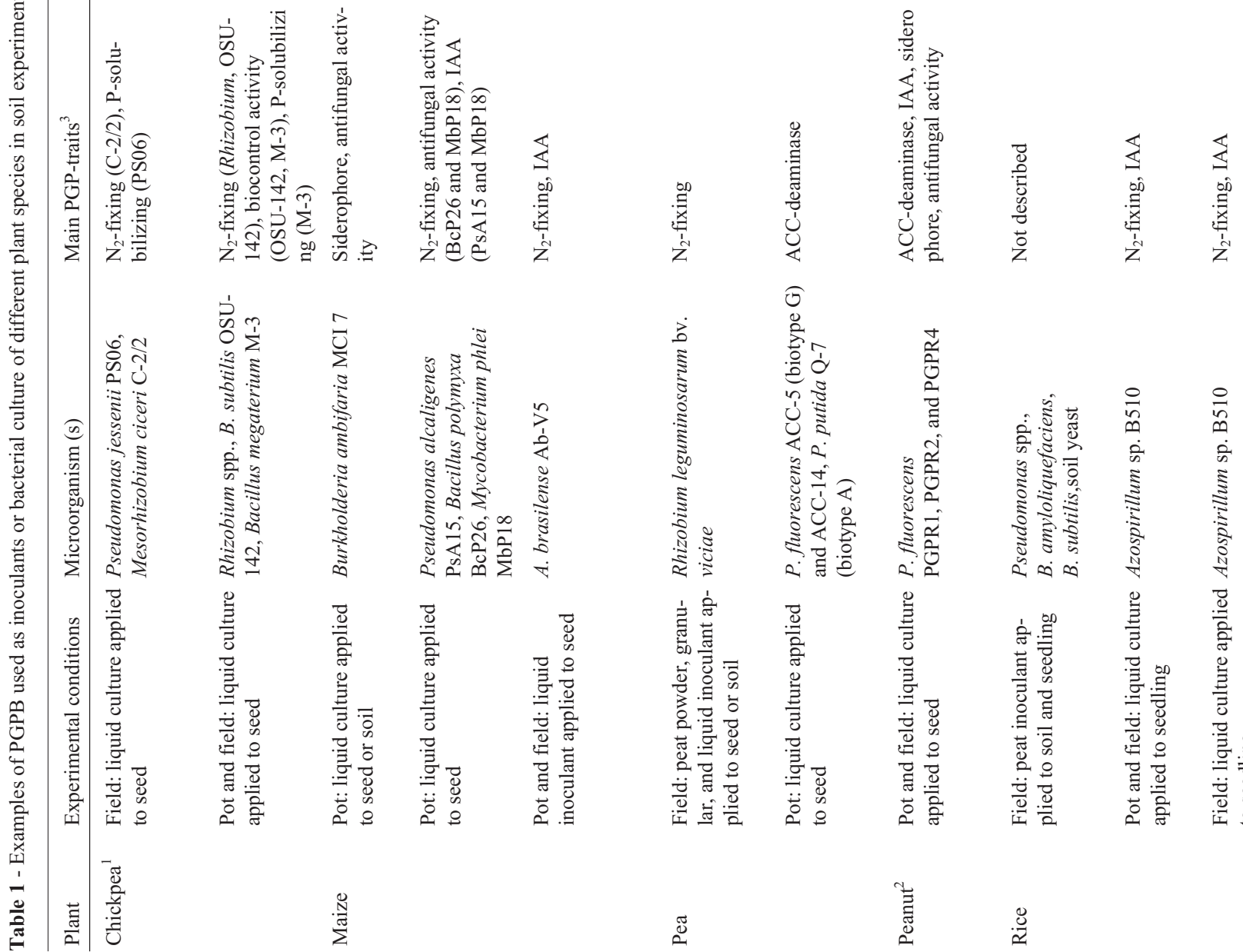

营 $\quad$ 总<smiles>C1CCCCC1</smiles>

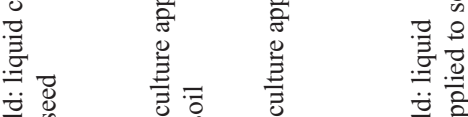

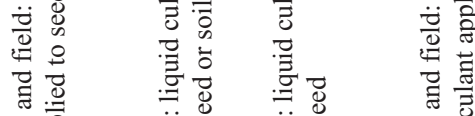

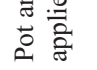

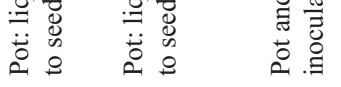
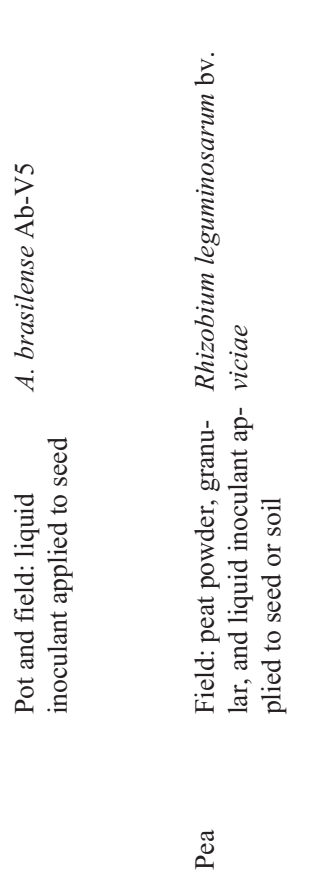

(ิ)

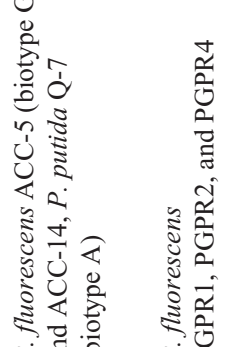

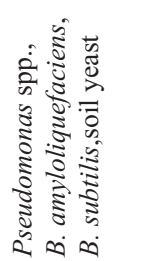

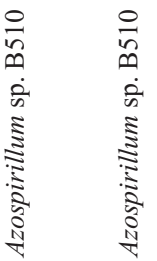

政

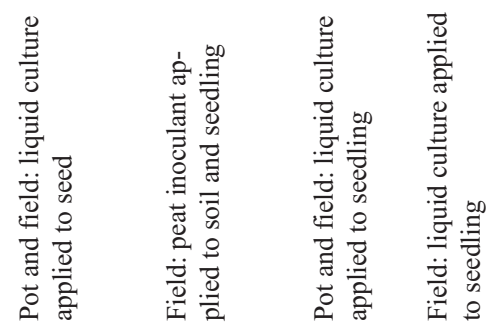

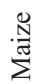

$\stackrel{8}{2}$

莺

$\frac{8}{2}$ 


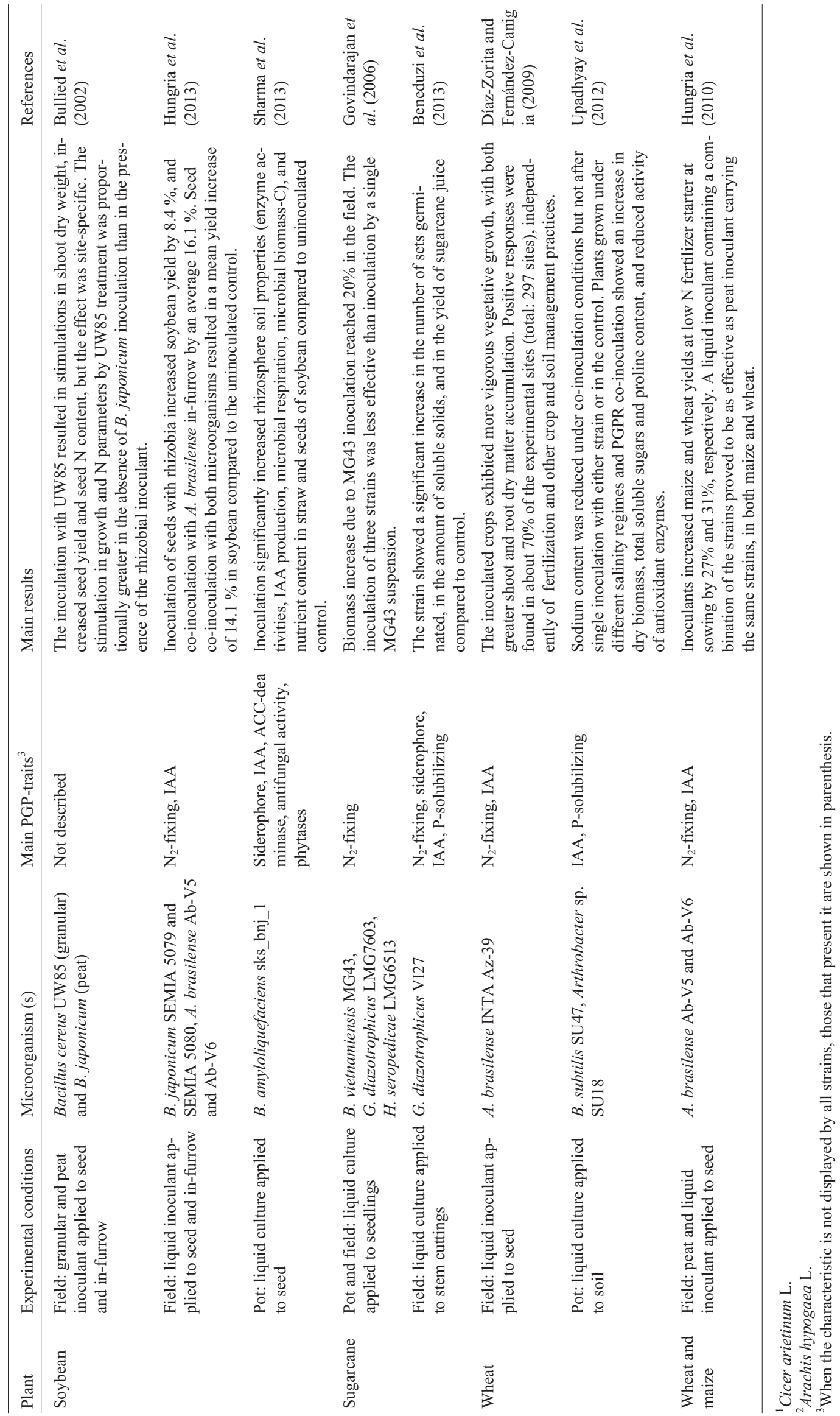


The well-studied flavonoids also vary with plant age and physiological state when exuded from legume rhizospheres, and induce nodD gene expression in rhizobial strains. NodD is a transcriptional activator of bacterial genes involved in the infection and nodule formation during the establishment of legume-rhizobia symbioses (Long, 2001). Similarly to flavonoids, several compounds secreted by roots modulate the relationships between plants and PGPB (Badri et al., 2009). Bacillus subtilis FB17, for instance, is attracted by L-malic acid, secreted by the roots of Arabidopsis thaliana infected with the foliar pathogen $P$. syringae pv tomato (Pst DC3000; Rudrappa et al., 2008). Profiles of secreted secondary metabolites, such as phenolic compounds, flavonoids and hydroxycinnamic derivatives, were different in rice cultivars (Nipponbare and Cigalon), according to inoculation with Azospirillum 4B and B510 strains. Interestingly, strains 4B and B510 preferentially increased the growth of the cultivar from which they were isolated; however, both strains effectively colonized either at the rhizoplane (4B and B510) or inside roots (B510) (Chamam et al., 2013).

Some molecules exudated from roots might act as antimicrobial agents against one organism and as stimuli for the establishment of beneficial interactions with regard to other organisms. For example, canavanine, a non-protein amino acid analog to arginine, secreted at high concentrations by many varieties of legume seeds, acts as an antimetabolite in many biological systems and also stimulates the adherence of rhizobia that detoxify this compound (Cai et al., 2009). In the Leguminosae family, canavanine is a major $\mathrm{N}$ storage compound in the seeds of many plants, and constitutes up to $13 \%$ of the dry weight of seeds (Rosenthal, 1972). Benzoxazinoids (BXs) are secondary metabolites synthesized by Poaceae during early plant growth stages. These molecules are effective in plant defense and allelopathy (Nicol et al., 1992; Zhang et al., 2000; Frey et al., 2009; Neal et al., 2012). However, qualitative and quantitative modifications of BXs production in maize were differentially induced according to inoculation with different Azospirillum strains (Walker et al., 2011a, b).

The quantitative and qualitative changes in the composition of the exudates result from the activation of biochemical defense systems through elicitors mimicking stresses in plants. Biotic and abiotic elicitors stimulate defense mechanisms in plant cells and greatly increase the diversity and amount of exudates (Cai et al., 2012). Several studies have reported that endophytic PGPB induce stress and defense responses, causing changes in plant metabolites that lead to the fine control of bacterial populations inside plant tissues (Miché et al., 2006; Chamam et al., 2013; Straub et al., 2013). Jasmonate is an important plantsignaling molecule that mediates biotic and abiotic stress responses and aspects of growth and development (Wasternack, 2007). Rocha (2007) showed that the jasmonate response is initiated prior to the establishment of an effective association. Following the inoculation of Miscanthus sinensis with $H$. frisingense GSF30T, transcriptome and proteome data showed the rapid and strong up-regulation of jasmonate-related genes in plants, and this effect was suppressed after the establishment of an association with bacteria (Straub et al., 2013).

\section{Bacterial root colonization}

Rhizosphere competence reflects variation in the ability of a PGPB to colonize plant roots during the transition from free-living to root-associated lifestyles. The attachment and colonization of roots are modulated through PGPB abilities involved in important processes for survival, growth, and function in soil (Cornforth and Foster, 2013). Associative and endophytic PGPB respond to plant exudates through the modulation of the expression of several genes, such as those associated with exopolysaccharide (EPS) biosynthesis and biofilm formation (Rudrappa et al., 2008; Meneses et al., 2011; Beauregard et al., 2013). Biofilms are surface-adherent microbial populations typically embedded within a self-produced matrix material (Fuqua and Greenberg, 2002). As previously mentioned, B. subtilis is attracted by L-malic acid secreted by $A$. thaliana. Moreover, bacterial biofilm formation is selectively triggered through L-malic acid, in a process dependent on the same gene matrix required for in vitro biofilm formation (Rudrappa et al., 2008; Beauregard et al., 2013). EPS biosynthesis is also required for biofilm formation and plant colonization by the endophyte G. diazotrophicus. A functional mutant of G. diazotrophicus PAL5 for EPS production did not attach to the rice root surface or exhibit endophytic colonization (Meneses et al., 2011).

Cell-cell communication via quorum sensing (QS) regulates root colonization and biocontrol (Danhorn and Fuqua, 2007). Quorum sensing involves intercellular signaling mechanisms that coordinate bacterial behavior, host colonization and stress survival to monitor population density (Danhorn and Fuqua, 2007; Schenk et al., 2012; He and Bauer, 2014). Plant-associated bacteria frequently employ this signaling mechanism to modulate and coordinate interactions with plants, including acylated homoserine lactones (AHLs) among proteobacteria and oligopeptides among gram-positive microbes (Danhorn and Fuqua, 2007). The endophytic G. diazotrophicus PAL5 strain colonizes a broad range of host plants, presenting QS comprising luxR and luxI homolog gene products and producing eight molecules of the AHL family (Bertini et al., 2014). The levels of QS were modified according to glucose concentration, the presence of other $\mathrm{C}$ sources and saline stress conditions.

Stress-induced bacterial genes are also associated with plant-bacterial interactions. The bacterial enzymes superoxide dismutase and glutathione reductase were crucial for the endophytic colonization of rice roots by $G$. diazotrophicus PAL5 (Alquéres et al., 2013). Bacillus amyloliquefaciens FZB42 genes involved in chemotaxis 
and motility were induced through exudates from P-deficient maize plants, whereas the exudates from $\mathrm{N}$-deficient plants triggered a general bacterial stress response (Carvalhais et al., 2013). The global gene expression of $A$. lipoferum 4B cells during interactions with different rice cultivars (Nipponbare and Cigalon) involved genes associated with reactive oxygen species (ROS) detoxification, multidrug efflux, and complex regulatory networks (Drogue et al., 2014). The cultivar-specific expression profiles of PGPB suggested host-specific adaptation (Drogue et al., 2014).

Moreover, microbial competition was closely associated with the root colonization efficiency of PGPB, as the exudation of different compounds attracts a great number of different microbial populations. The deposition of nutrients in the plant rhizosphere (rhizodeposition) supports higher microbial growth than the surrounding soil, a phenomenon referred to as the "rhizosphere effect" (Rovira, 1965; Dunfield and Germida, 2003; Mougel et al., 2006). This intense molecular communication surrounding the roots provides a broad range of microbe-microbe interactions, making this environment highly competitive among soil bacteria. Microbial competition and activities include, for example, motility (Capdevila et al., 2004; de Weert et al., 2002), attachment (Buell and Anderson, 1992; Rodriguez-Navarro et al., 2007), growth (Browne et al., 2009; Miller et al., 2010), stress resistance (Espinosa-Urgel et al., 2000; Martinez et al., 2009), secondary metabolite production (Abbas et al., 2002; Haas and Defago, 2005), and quorum sensing (Edwards et al., 2009; Ramachandran et al., 2011).

\section{Soil health}

Soil is a heterogeneous mixture of different organisms and organic and mineral substances present in three phases: solid, liquid, and gaseous (Kabata-Pendias, 2004). The physical forces and natural grouping of particles result in the formation of soil aggregates of different sizes, arrangements and stabilities, which are the basic units of soil structure (Lynch and Bragg, 1985). Soil aggregation is influenced by several factors, such as soil mineralogy, cycles of wetting and drying, the presence of iron and aluminum oxides as a function of soil $\mathrm{pH}$ range, and clay and organic material contents (Lynch and Bragg, 1985; Cammeraat and Imeson, 1998; Castro Filho et al., 2002; Majumder and Kuzyakov, 2010; Vogel et al., 2014). Plant roots directly contribute to the stability of soil aggregates through the inherent abundance of these structures in organic matter and the production of exudates stimulating microbial activity, and indirectly by the production of EPS (Leigh and Coplin, 1992; Alami et al., 2000; Schmidt et al., 2011).

The fine spatial heterogeneity of soils results in a complex mosaic of gradients selecting for or against bacterial growth (Vos et al., 2013). The microbial biomass decreases with soil depth, and changes in the community composition reflect substrate specialization (Schmidt et al., 2011). The distribution of micro $(<250 \mu \mathrm{m})$ and macro $(>250 \mu \mathrm{m})$-aggregates provides microhabitats differentially assembled in terms of temperature, aeration, water retention and movement (Dinel et al., 1992; Zhang, 1994; Denef et al., 2004; Schmidt et al., 2011). Soil aggregates of different pore sizes influence $C$ sequestration and the availability of nutrients (Zhang et al., 2013), and low pore connectivity due to low water potential increases the diversity of bacterial communities in the soil (Carson et al., 2010; Ruamps et al., 2011). Moreover, the moisture content, pore size and habitat connectivity differently impact the expansion of motile rod-shaped and filamentous bacterium types (Wolf et al., 2013).

Soil stability results from a combination of biotic and abiotic characteristics, and the microbial communities could provide a quantitative measure of soil health, as these bacteria determine ecosystem functioning according to biogeochemical processes (Griffiths and Philippot, 2012). Soil health defines the capacity of soil to function as a vital living system, within ecosystem and land-use boundaries, to sustain plant and animal productivity, maintain or enhance water and air quality, and promote plant and animal health (Doran and Zeiss, 2000). The factors controlling broadrange soil health comprise chemical, physical, and biological features, such as soil type, climate, cropping patterns, use of pesticides and fertilizers, availability of $\mathrm{C}$ substrates and nutrients, toxic material concentrations, and the presence or absence of specific assemblages and types of organisms (Doran and Zeiss, 2000; Young and Ritz, 1999; Kibblewhite et al., 2008).

The sustainable management of soils requires soil monitoring, including biological indicators such as microbial communities, which provide many potentially interesting indicators for environmental monitoring in response to a range of stresses or disturbances (Pulleman et al., 2012). Community stability is a functional property that focuses on community dynamics in response to perturbation: the return to a state of equilibrium following perturbation is the ability to resist to changes, which is called resistance; the rate of return to a state of equilibrium following perturbation is called resilience (Robinson et al., 2010). Soil functional resilience is governed by the effects of the physicochemical structure on microbial community composition and physiology (Griffiths et al., 2008). Microbial catabolic diversity is reduced through intensive land-use, which may have implications for the resistance of the soils to stress or disturbance (Degens et al., 2001; Ding et al., 2013).

Modern land-use practices highly influence the factors controlling soil health because, while these techniques increase the short-term supply of material goods, over time these practices might undermine many ecosystem services on regional and global scales (Foley et al., 2005). Soil disturbances operate at various spatial and temporal scales and mediate soil spatial heterogeneity. For instance, such dis- 
turbances may reduce the biomass of dominant organisms or provoke alterations in the physical structure of the soil substrate (Ettema and Wardle, 2002). Cultivation intensity reduces $\mathrm{C}$ content and changes the distribution and stability of soil aggregates, leading to a loss of C-rich macroaggregates and an increase of C-depleted microaggregates in soils (Six et al., 2000). Moreover, soil aggregation is a major ecosystem process directly impacted, via intensified land-use, by soil disturbances, or indirectly through impacts on biotic and abiotic factors that affect soil aggregates (Barto et al., 2010).

The physical disruption spectrum induced by tillage presents various degrees of soil disturbance and associations between no-tillage or minimum tillage and the 'beneficial' effects on soil microorganisms (Elliott and Coleman, 1988; Derpsch et al., 2014). The primary effect of tillage is the physical disturbance of the soil profile through alterations in the habitat space, water and substrate distribution and the spatial arrangement of pore pathways (Young and Ritz, 1999). Accumulated evidence suggests that conserved tillage systems, including no-tillage and reduced tillage, effectively reverse the disadvantage of conventional tillage in depleting the carbon stock through increases in the abundance and activity of the soil biota (Zhang et al., 2013). Lower microbial biomass in arable land likely reflects soil disturbance through tillage and the tillage-induced changes in soil properties (Cookson et al., 2008).

Disturbances alter the immediate environment, potentially leading to repercussions or direct alterations to this community (Shade et al., 2012). The manipulation of soil structure is one of the principal mechanisms for the regulation of microbial dynamics, at both the small and field scale (Elliott and Coleman, 1988; Derpsch et al., 2014). The microscale impact in crop soil under grassland, tillage, and no-tillage systems resulted in micro-aggregates containing similar bacterial communities, despite the land management practice, whereas strong differences were observed between communities inhabiting macro-aggregates (Constancias et al., 2014). In this same study, tillage decreased the density and diversity of bacteria from 74 to $22 \%$ and from 11 to $4 \%$, respectively, and changed taxonomic groups in micro and macro-aggregates. These changes led to the homogenization of bacterial communities, reflecting the increased protection of micro-aggregates.

The combination of crop rotation with legumes, tillage management and soil amendments considerably influences the microbiotic properties of soil. Conventional agriculture systems, according to the FAO definition, use no tillage and have seeds placed at a proper depth in untilled soil, with previous crops or cover crop residues retained on the soil surface. In a no-tillage system, crop residue management plays an equally important role in minimizing and even avoiding soil disturbance (Derpsch et al., 2014). More research will expand our understanding of the combined effects of these alternatives on feedback between soil micro- biotic properties and soil organic $\mathrm{C}$ accrual (Ghimire et al., 2014). However, the terms "reduced tillage" or "minimum tillage" or other degrees of tillage disturbance have been coined as no-tillage systems, and this term has been revised to "conservation agriculture systems" as a more holistic description (Derpsch et al., 2014). These authors also revised other terms associated with no-tillage systems.

\section{Conclusions}

At a global scale, the effects of continuous agricultural practices such as fertilization can cause serious damage to the environment. Inoculation is one of the most important sustainable practices in agriculture, because microorganisms establish associations with plants and promote plant growth by means of several beneficial characteristics. Endophytes are suitable for inoculation, reflecting the ability of these organisms for plant colonization, and several studies have demonstrated the specific and intrinsic communication among bacteria and plant hosts of different species and genotypes.

The combination of different methodologies with these bacteria, such as identification of plant growthpromoting characteristics, the identification of bacterial strains, as well as assays of seed inoculation in laboratory conditions and cultivation experiments in the field, are part of the search for new technologies for agricultural crops. Thus, when this search shows a potential bacterial inoculant, adequate for reintroduction in the environment, many genera such as Azospirillum, Bacillus and Rhizobium may be primary candidates.

Finally, the search for beneficial bacteria is important for the development of new and efficient inoculants for agriculture. Also important are investments in technologies that can contribute to increase the inoculum efficiency and the survival rate of bacteria adherent to the seeds, which are other essential factors for successful inoculation. Thus, the introduction of beneficial bacteria in the soil tends to be less aggressive and cause less impact to the environment than chemical fertilization, which makes it a sustainable agronomic practice and a way of reducing the production costs.

\section{References}

Abbas A, Morrissey JP, Marquez PC, Sheehan MM, Delany IR and O'Gara F (2002) Characterization of interactions between the transcriptional repressor PhlF and its binding site at the phlA promoter in Pseudomonas fluorescens F113. J Bacteriol 184:3008-3016.

Acuña JJ, Jorquera MA, Martínez OA, Menezes-Blackburn D, Fernández MT, Marschner P, Greiner R and Mora ML (2011) Indole acetic acid and phytase activity produced by rhizosphere bacilli as affected by $\mathrm{pH}$ and metals. J Soil Sci Plant Nutr 11:1-12.

Adesemoye AO, Torbert HA and Kloepper JW (2009) Plant growth-promoting rhizobacteria allow reduced application rates of chemical fertilizers. Microb Ecol 58:921-929. 
Aira M, Gómez-Brandón M, Lazcano C, Baath E and Domínguez J (2010) Plant genotype strongly modifies the structure and growth of maize rhizosphere microbial communities. Soil Biol Biochem 42:2276-2281.

Akbari GA, Arab SM, Alikhani HA, Allahdadi I and Arzanesh $\mathrm{MH}$ (2007) Isolation and selection of indigenous Azospirillum spp. and the IAA of superior strains effects on wheat roots. World J Agric Sc 3:523-529.

Alami Y, Achouak W, Marol C and Heulin T (2000) Rhizosphere soil aggregation and plant growth promotion of sunflowers by an exopolysaccharide-producing Rhizobium sp. strain isolated from sunflower roots. Appl Environ Microbiol 66:3393-3398.

Ali S, Trevor CC and Glick BR (2014) Amelioration of high salinity stress damage by plant growth-promoting bacterial endophytes that contain ACC deaminase. Plant Physiol Biochem 80:160-167.

Alquéres S, Meneses C, Rouws L, Rothballer M, Baldani I, Schmid M and Hartmann A (2013) The bacterial superoxide dismutase and glutathione reductase are crucial for endophytic colonization of rice roots by Gluconacetobacter diazotrophicus PAL5. Mol Plant-Microbe Interact 26:937945.

Alves BJR, Boddey RM and Urquiaga S (2004) The success of BNF in soybean in Brazil. Plant Soil 252:1-9.

Ambrosini A, Beneduzi A, Stefanski T, Pinheiro FG, Vargas LK and Passaglia LMP (2012) Screening of plant growth promoting rhizobacteria isolated from sunflower (Helianthus annuus L.). Plant Soil 356:245-264.

Andrews SC, Robinson AK and Rodríguez-Quinõnes F (2003) Bacterial iron homeostasis. FEMS Microbiol Rev 27:215237.

Arnold W, Rump A, Klipp W, Priefer UB and Pühler A (1988) Nucleotide sequence of a 24,206-base-pair DNA fragment carrying the entire nitrogen fixation gene cluster of Klebsiella pneumoniae. J Mol Biol 203:715-738.

Arshad M, Saleem M and Hussain S (2007) Perspectives of bacterial ACC deaminase in phytoremediation. Trends Biotechnol 25:356-362.

Arshad M, Shaharoona B and Mahmood T (2008) Inoculation with Pseudomonas spp. containing ACC-deaminase partially eliminates the effects of drought stress on growth, yield, and ripening of pea (Pisum sativum L.). Pedosphere 18:611-620.

Bacon CW and Hinton DM (2006) Bacterial endophytes: The endophytic niche, its occupants, and its utility. In: Gnanamanickam SS (Ed) Plant-Associated Bacteria. Springer, Netherlands, pp 155-194.

Badri DV and Vivanco JM (2009) Regulation and function of root exudates. Plant Cell Environ 32:666-681.

Bais HP, Weir TL, Perry LG, Gilroy S and Vivanco JM (2006) The role of root exudates in rhizosphere interactions with plants and other organisms. Annu Rev Plant Biol 57:233266.

Baldani JI, Caruso L, Baldani VLD, Goi SR and Döbereiner J (1997) Recent advances in BNF with non-legume plants. Soil Biol Biochem 29:911-922.

Bal HB, Nayak L, Das S and Adhya TK (2013) Isolation of ACC deaminase producing PGPR from rice rhizosphere and evaluating their plant growth promoting activity under salt stress. Plant Soil 366:93-105.
Bao Z, Sasaki K, Okubo T, Ikeda S, Anda M, Hanzawa E, Kaori K, Tadashi S, Hisayuki M and Minamisawa K (2013) Impact of Azospirillum sp. B510 inoculation on rice-associated bacterial communities in a paddy field. Microbes Environ 28:487-490.

Barto EK, Alt F, Oelmann Y, Wilcke W and Rillig MC (2010) Contributions of biotic and abiotic factors to soil aggregation across a land use gradient. Soil Biol Biochem 42:23162324.

Bashan Y, Holguin G and De-Bashan LE (2004) Azospirillum-plant relations physiological, molecular, agricultural, and environmental advances (1997-2003). Can J Microbiol 50:521-577.

Baudoin E, Lerner A, Mirza MS, Zemrany HE, Prigent-Combaret C, Jurkevich E, Spaepen S, Vanderleyden J, Nazaret S, Okon Y, et al. (2010) Effects of Azospirillum brasilense with genetically modified auxin biosynthesis gene ipdC upon the diversity of the indigenous microbiota of the wheat rhizosphere. Res Microbiol 161:219-226.

Beauregard PB, Chai Y, Vlamakis H, Losick R and Kolter R (2013) Bacillus subtilis biofilm induction by plant polysaccharides. Proc Natl Acad Sci USA 110:E1621-E1630.

Beneduzi A, Moreira F, Costa PB, Vargas LK, Lisboa BB, Favreto R, Baldani JI and Passaglia LMP (2013) Diversity and plant growth promoting evaluation abilities of bacteria isolated from sugarcane cultivated in the South of Brazil. Appl Soil Ecol 63:94-104.

Bergsma-Vlami M, Prins ME and Raaijmakers JM (2005) Influence of plant species on population dynamics, genotypic diversity and antibiotic production in the rhizosphere by indigenous Pseudomonas spp. FEMS Microbiol Ecol 52:59-69.

Bertalan M, Albano R, de Pádua V, Rouws L, Rojas C, Hemerly A, Teixeira K, Schwab S, Araujo J, Oliveira A et al. (2009) Complete genome sequence of the sugarcane nitrogenfixing endophyte Gluconacetobacter diazotrophicus PAl5. BMC Genomics 10:e450.

Bertini EV, Peñalver CGN, Leguina AC, Irazusta VP and De Figueroa LI (2014) Gluconacetobacter diazotrophicus PAL5 possesses an active quorum sensing regulatory system. Antonie van Leeuwenhoek 106:497-506.

Boucher Y, Douady CJ, Papke RT, Walsh DA, Boudreau MER, Nesbo CL, Case J and Doolittle WF (2003) Lateral gene transfer and the origins of prokaryotic groups. Annu Rev Genet 37:283-328.

Bullied JW, Buss WTJ and Vessey KJ (2002) Bacillus cereus UW85 inoculation effects on growth, nodulation, and $\mathrm{N}$ accumulation in grain legumes: Field studies. Can J Plant Sci 82:291-298.

Browne P, Rice O, Miller SH, Burke J, Dowling DN, Morrissey JP and O'Gara F (2009) Superior inorganic phosphate solubilization is linked to phylogeny within the Pseudomonas fluorescens complex. Appl Soil Ecol 43:131-138.

Buell CR and Anderson AJ (1992) Genetic analysis of the aggA locus involved in agglutination and adherence of Pseudomonas putida, a beneficial fluorescent pseudomonad. Mol Plant Microbe Interact 5:154-162.

Cai T, Cai W, Zhang J, Zheng H, Tsou AM, Xiao L, Zhong Z and Zhu J (2009) Host legume-exuded antimetabolites optimize the symbiotic rhizosphere. Mol Microbiol 73:507-517.

Cai Z, Kastell A, Knorr D and Smetanska I (2012) Exudation: An expanding technique for continuous production and release 
of secondary metabolites from plant cell suspension and hairy root cultures. Plant cell reports 31:461-477.

Cammeraat LH and Imeson AC (1998) Deriving indicators of soil degradation from soil aggregation studies in southeastern Spain and southern France. Geomorphology 23:307-321.

Capdevila S, Martinez-Granero FM, Sanchez-Contreras M, Rivilla R and Martin M (2004) Analysis of Pseudomonas fluorescens F113 genes implicated in flagellar filament synthesis and their role in competitive root colonization. Microbiology-SGM 150:3889-3897.

Carson JK, Gonzalez-Quiñones V, Murphy DV, Hinz C, Shaw JA and Gleeson DB (2010) Low pore connectivity increases bacterial diversity in soil. Appl Environ Microbiol 76:3936-3942.

Carvalhais LC, Dennis PG, Fan B, Fedoseyenko D, Kierul K, Becker A, Von Wiren N and Borriss R (2013) Linking plant nutritional status to plant-microbe interactions. PLoS One 8:e68555

Cassán FD and Garcia de Salamone I (2008) Azospirillum sp.: Cell Physiology, Plant Interactions and Agronomic Research in Argentina. Asociación Argentina de Microbiologia, Argentina, $276 \mathrm{p}$.

Castro Filho C, Lourenço A, De F Guimarães M and Fonseca ICB (2002) Aggregate stability under different soil management systems in a red latosol in the state of Parana, Brazil. Soil Tillage Res 65:45-51.

Chabot R, Antoun H and Cescas MP (1993) Stimulation de la croissance du mais et de la laitue romaine par desmicroorganismes dissolvant le phosphore inorganique. Can J Microbiol 39:941-7.

Chamam A, Sanguin H, Bellvert F, Meiffren G, Comte G, Wisniewski-Dyé F, Bertrand C and Prigent-Combaret C (2013) Plant secondary metabolite profiling evidences strain-dependent effect in the Azospirillum-Oryza sativa association. Phytochemistry 87:65-77.

Cheng Q (2008) Perspectives in biological nitrogen fixation research. J Integr Plant Biol 50:784-796.

Chen YP, Rekha PD, Arun AB, Shen FT, Lai WA and Young CC (2006) Phosphate solubilizing bacteria from subtropical soil and their tricalcium phosphate solubilizing abilities. Appl Soil Ecol 34:33-41.

Chen Y, Fan JB, Du L, Xu H, Zhang QY and He YQ (2014) The application of phosphate solubilizing endophyte Pantoea dispersa triggers the microbial community in red acidic soil. Appl Soil Ecol 84:235-244.

Chung H, Park M, MadhaiyanaM, Seshadri S, Song J, Cho H and Sa T (2005) Isolation and characterization of phosphate solubilizing bacteria from the rhizosphere of crop plants of Korea. Soil Biol Biochem 3:1970-1974.

Ciccillo F, Fiore A, Bevivino A, Dalmastri C, Tabacchioni S and Chiarini L (2002) Effects of two different application methods of Burkholderia ambifaria MCI7 on plant growth and rhizospheric bacterial diversity. Environ Microbiol 4:238245 .

Clayton GW, Rice WA, Lupwayi NZ, Johnston AM, Lafond GP, Grant CA and Walley F (2004) Inoculant formulation and fertilizer nitrogen effects on field pea: Nodulation, $\mathrm{N}_{2}$ fixation and nitrogen partitioning. Can J Plant Sci 84:79-88.

Cong PT, Dung TD, Hien TM, Hien NT, Choudhury AT, Kecskés ML and Kennedy IR (2009) Inoculant plant growthpromoting microorganisms enhance utilisation of urea-N and grain yield of paddy rice in southern Vietnam. Eur J Soil Biol 45:52-61.

Constancias F, Prévost-Bouré NC, Terrat S, Aussems S, Nowak V, Guillemin JP, Bonnotte A, Biju-Duval L, Navel A, Martins JMF, et al. (2014) Microscale evidence for a high decrease of soil bacterial density and diversity by cropping. Agron Sustainable Dev 34:831-840.

Cookson WR, Murphy DV and Roper MM (2008) Characterizing the relationships between soil organic matter components and microbial function and composition along a tillage disturbance gradient. Soil Biol Biochem 40:763-777.

Cornforth DM and Foster KR (2013) Competition sensing: The social side of bacterial stress responses. Nat Rev Microbiol 11:285-293.

Costa P, Beneduzi A, Souza R, Schoenfeld R, Vargas LK and Passaglia LMP (2013) The effects of different fertilization conditions on bacterial plant growth promoting traits: Guidelines for directed bacterial prospection and testing. Plant Soil 368:267-280.

Costa PB, Granada CE, Ambrosini A, Moreira F, Souza R, Passos JFM, Arruda L and Passaglia LMP (2014) A model to explain plant growth promotion traits: A multivariate analysis of 2,211 bacterial isolates. PLoS One 9:e116020.

Danhorn T and Fuqua C (2007) Biofilm formation by plantassociated bacteria. Annu Rev Microbiol 61:401-422.

Denef K, Six J, Merckx R and Paustian K (2004) Carbon sequestration in microaggregates of no-tillage soils with different clay mineralogy. Soil Sci Soc Am J 68:1935-1944.

Degens BP, Schipper LA, Sparling GP and Duncan LC (2001) Is the microbial community in a soil with reduced catabolic diversity less resistant to stress or disturbance? Soil Biol Biochem 33:1143-1153.

Derpsch R, Franzluebbers AJ, Duiker SW, Reicosky DC, Koeller K, Friedrich T, Sturny WG, Sá JCM and Weiss K (2014) Why do we need to standardize no-tillage research? Soil Tillage Res 137:16-22.

Dey R, Pal KK, Bhatt DM and Chauhan SM (2004) Growth promotion and yield enhancement of peanut (Arachis hypogaea L.) by application of plant growth-promoting rhizobacteria. Microbiol Res 159:371-394.

de Weert S, Vermeiren H, Mulders IHM, Kuiper I, Hendrickx N, Bloemberg GV, Vanderleyden J, De Mot R and Lugtenberg BJJ (2002) Flagella-driven chemotaxis towards exudate components is an important trait for tomato root colonization by Pseudomonas fluorescens. Mol Plant Microbe Interact 15:1173-1180.

Díaz-Zorita M and Fernández-Canigia MV (2009) Field performance of a liquid formulation of Azospirillum brasilense on dryland wheat productivity. Eur J Soil Biol 45:3-11.

Dimkpa C, Weinand T and Asch F (2009a) Plant-rhizobacteria interactions alleviate abiotic stress conditions. Plant Cell Environ 32:1682-1694.

Dimkpa CO, Merten D, Svatos A, Büchel G and Kothe E (2009b) Siderophores mediate reduced and increased uptake of cadmium by Streptomyces tendae F4 and sunflower (Helianthus annuus), respectively. J Appl Microbiol 5:687-1696.

Dinel H, Levesque PEM, Jambu P and Righi D (1992) Microbial activity and long-chain aliphatics in the formation of stable soil aggregates. Soil Sci Soc Am J 56:1455-1463.

Ding GC, Piceno YM, Heuer H, Weinert N, Dohrmann AB, Carrillo A, Andersen GL, Castellanos T, Tebbe CC and 
Smalla K (2013) Changes of soil bacterial diversity as a consequence of agricultural land use in a semi-arid ecosystem. PLoS One 8:e59497.

Dixon R and Kahn D (2004) Genetic regulation of biological nitrogen fixation. Nat Rev Microbiol 2:621-631.

Dobbelaere S, Croonenborghs A, Thys A, Broek AV and Vanderleyden J (1999) Phytostimulatory effect of Azospirillum brasilense wild type and mutante strains altered in IAA production on wheat. Plant Soil 212:155-164.

Domenech J, Reddy MS, Kloepper JW, Ramos B and GutierrezMañero J (2006) Combined application of the biological product LS213 with Bacillus, Pseudomonas or Chryseobacterium for growth promotion and biological control of soil-borne diseases in pepper and tomato. BioControl 51:245-258.

Doran JW and Zeiss MR (2000) Soil health and sustainability: Managing the biotic component of soil quality. Appl Soil Ecol 15:3-11.

Drogue B, Sanguin H, Borland S, Prigent-Combaret C and Wisniewski-Dyé F (2014) Genome wide profiling of Azospirillum lipoferum 4B gene expression during interaction with rice roots. FEMS Microbiol Ecol 87:543-555.

Dunfield KE and Germida JJ (2003) Seasonal changes in the rhizosphere microbial communities associated with field-grown genetically modified canola (Brassica napus). Appl Environ Microbiol 69:7310-7318.

Edwards A, Frederix M, Wisniewski-Dye F, Jones J, Zorreguieta A and Downie JA (2009) The cin and rai quorum-sensing regulatory systems in Rhizobium leguminosarum are coordinated by ExpR and CinS, a small regulatory protein coexpressed with CinI. J Bacteriol 191:3059-3067.

Egamberdiyeva D (2007) The effect of plant growth promoting bacteria on growth and nutrient uptake of maize in two different soils. Appl Soil Ecol 36:184-189.

Elbeltagy A, Nishioka K, Sato T, Suzuki H, Ye B, Hamada T, Isawa T, Mitsui H and Minamisawa K (2001) Endophytic colonization and in plant nitrogen fixation by a Herbaspirillum sp. isolated from wild rice species. Appl Environ Microbiol 67:5285-5293.

Elkoca E, Kantar F, and Sahin F (2008) Influence of nitrogen fixing and phosphorus solubilizing bacteria on the nodulation, plant growth, and yield of chickpea. J Plant Nut 31:157-171.

Elliott ET and Coleman DC (1988) Let the soil work for us. Ecol Bull 39:23-32.

Espinosa-Urgel M, Salido A and Ramos JL (2000) Genetic analysis of functions involved in adhesion of Pseudomonas putida to seeds. J Bacteriol 182:2363-2369.

Estrada GA, Baldani VLD, Oliveira DM, Urquiaga S and Baldani JV (2013) Selection of phosphate-solubilizing diazotrophic Herbaspirillum and Burkholderia strains and their effect on rice crop yield and nutrient uptake. Plant Soil 369:115-129.

Ettema CH and Wardle DA (2002) Spatial soil ecology. Trends Ecol Evol 17:177-183.

Farajzadeh D, Yakhchali B, Aliasgharzad N, Sokhandan-Bashir N and Farajzadeh M (2012) Plant growth promoting characterization of indigenous Azotobacteria isolated from soils in Iran. Curr Microbiol 64:397-403.

Farina RA, Beneduzi A, Ambrosini A, Campos SB, Lisboa BB, Wendisch V, Vargas LK and Passaglia LMP (2012) Diversity of plant growth-promoting rhizobacteria communities associated with the stages of canola growth. Appl Soil Ecol 55:44-52.

Ferreira AS, Pires RR, Rabelo PG, Oliveira RC, Luz JMQ and Brito CH (2013) Implications of Azospirillum brasilense inoculation and nutrient addition on maize in soils of the Brazilian Cerrado under greenhouse and field conditions. Appl Soil Ecol 72:103-108.

Foley JA, DeFries R, Asner GP, Barford C, Bonan G, Carpenter SR, Chapin FS, Coe MT, Daily GC, Gibbs HK, et al. (2005) Global consequences of land use. Science 309:570-574.

Franche C, Lindström K and Elmerich C (2009) Nitrogen-fixing bacteria associated with leguminous and non-leguminous plants. Plant Soil 321:35-59.

Frey M, Schullehner K, Dick R, Fiesselmann A and Gierl A (2009) Benzoxazinoid biosynthesis, a model for evolution of secondary metabolic pathways in plants. Phytochemistry 70:1645-1651.

Fuqua C and Greenberg EP (2002) Listening in on bacteria: Acyl-homoserine lactone signalling. Nat Rev Mol Cell Biol 3:685-95.

Gaiero JR, McCall CA, Thompson KA, Day NJ, Best AS and Dunfield KE (2013) Inside the root microbiome: Bacterial root endophytes and plant growth promotion. Am J Bot 100:1738-1750.

Garcia de Salamone IE, Döbereiner J, Urquiaga S and Boddey RM (1996) Biological nitrogen fixation in Azospirillum strain maize genotype associations as evaluated by ${ }^{15} \mathrm{~N}$ isotope dilution technique. Biol Fertil Soils 23:249-256.

Ghimire R, Norton JB, Stahl PD and Norton U (2014) Soil microbial substrate properties and microbial community responses under irrigated organic and reduced-tillage crop and forage production systems. PLoS One 9:e103901.

Glass ADM (1989) Plant Nutrition: An Introduction to Current Concepts. Jones and Bartlett Publishers, Boston, 234 p.

Glick BR (2005) Modulation of plant ethylene levels by the bacterial enzyme ACC deaminase. FEMS Microbiol Lett 251:1-7.

Glick BR (2010) Using soil bacteria to facilitate phytoremediation. Biotechnol Adv 28:367-374.

Glick B (2012) Plant growth-promoting bacteria: Mechanisms and applications. Scientifica 2012:1-15.

Govindarajan M, Balandreau J, Muthukumarasamy R, Revathi G and Lakshminarasimhan C (2006) Improved yield of micropropagated sugarcane following inoculation by endophytic Burkholderia vietnamiensis. Plant Soil 280:239-252.

Govindarajan M, Balandreau J, Kwon SW, Weon HY and Lakshminarasimhan C (2008) Effects of the inoculation of Burkholderia vietnamensis and related endophytic diazotrophic bacteria on grain yield of rice. Microb Ecol 55:21-37.

Granada C, Costa PB, Lisboa BB, Vargas LK and Passaglia LMP (2013) Comparison among bacterial communities present in arenized and adjacent areas subjected to different soil management regimes. Plant Soil 373:339-358.

Gray EJ and Smith DL (2005) Intracellular and extracellular PGPR: Commonalities and distinctions in the plantbacterium signaling processes. Soil Biol Biochem 37:395412.

Griffiths BS, Hallett PD, Kuan HL, Gregory AS, Watts CW and Whitmore AP (2008) Functional resilience of soil microbial communities depends on both soil structure and microbial community composition. Biol Fertil Soils 44:745-754. 
Griffiths BS and Philippot L (2012) Insights into the resistance and resilience of the soil microbial community. FEMS Microbiol Rev 37:112-129.

Grover M, Ali SKZ, Sandhya V, Rasul A and Venkateswarlu B (2011) Role of microorganisms in adaptation of agriculture crops to abiotic stresses. World J Microbiol Biotechnol 27:1231-1240.

Gulati HK, Chadha BS and Saini HS (2007) Production and characterization of thermostable alkaline phytase from Bacillus laevolacticus isolated from rhizosphere soil. J Ind Microbiol Biot 34:91-98.

Guttman D, McHardy AC and Schulze-Lefert P (2014) Microbial genome-enabled insights into plant-microorganism interactions. Nat Rev Genet 15:797-813.

Haas D and Defago G (2005) Biological control of soil-borne pathogens by fluorescent pseudomonads. Nat Rev Microbiol 3:307-319.

He K and Bauer CE (2014) Chemosensory signaling systems that control bacterial survival. Trends Microbiol 22:389-398.

Holford ICR (1997) Soil phosphorus, its measurements and its uptake by plants. Austr J Soil Res 35:227-239.

Hungria M, Campo RJ, Souza EM and Pedrosa FO (2010) Inoculation with selected strains of Azospirillum brasilense and $A$. lipoferum improves yields of maize and wheat in Brazil. Plant Soil 331:413-425.

Hungria M, Nogueira MA and Araujo RS (2013) Co-inoculation of soybeans and common beans with rhizobia and azospirilla: Strategies to improve sustainability. Biol Fertil Soils 49:791-801.

Idriss EE, Makarewicz O, Farouk A, Rosner K, Greiner R, Bochow H, Richter T and Borriss R (2002) Extracellular phytase activity of Bacillus amyloliquefaciens FZB45 contributes to its plant-growth-promoting effect. Microbiol 148:2097-2109.

Ikeda AG, Bassani LL, Adamoski D, Stringari D, Cordeiro VK, Glienke C, Maria Steffens BR, Hungria M and GalliTerasawa LV (2013) Morphological and genetic characterization of endophytic bacteria isolated from roots of different maize genotypes. Microb Ecol 65:154-160.

Isawa T, Yasuda M, Awazaki H, Minamisawa K, Shinozaki S and Nakashita H (2010) Azospirillum sp. strain B510 enhances rice growth and yield. Microbes Environ 25:58-61.

Jalili F, Khavazi K, Pazira E, Nejati A, Rahmani HA, Sadaghiani HR and Miransari M (2009) Isolation and characterization of ACC deaminase-producing fluorescent pseudomonads, to alleviate salinity stress on canola (Brassica napus L.) growth. J Plant Physiol 166:667-674.

James EK, Olivares FL, Baldani JI and Dobereiner J (1997) Herbaspirillum, an endophytic diazotroph colonizing vascular tissue of Sorghum bicolor L. Moench. J Exp Bot 48:785-798.

Jensen JB, Egsgaard H, Onckelen HV and Jochimsen BU (1995) Catabolism of Indole-3- Acetic Acid and 4- and 5-Chloroindole-3-Acetic Acid in Bradyrhizobium japonicum. J Bacteriol 177:5762-5766.

Jones DL (1998) Organic acids in the rhizosphere - A critical review. Plant Soil 205:25-44

Jorquera MA, Hernández MT, Rengel Z, Marschner P and Mora ML (2008) Isolation of culturable phosphobacteria with both phytate-mineralization and phosphate-solubilization activity from the rhizosphere of plants grown in a volcanic soil. Biol Fertil Soils 44:1025-1034.

Jorquera MA, Crowley DE, Marschner P, Greiner R, Fernández MT, Romero D, Menezes-Blackburn D and De La Luz MM (2011) Identification of b-propeller phytase-encoding genes in culturable Paenibacillus and Bacillus spp. from the rhizosphere of pasture plants on volcanic soils. FEMS Microbiol Ecol 75:163-172.

Kabata-Pendias A (2004) Soil-plant transfer of trace elements-an environmental issue. Geoderma 122:143-149.

Kerovuo J, Lauraeus M, Nurminen P, Kalkkinen N and Apajalahti $\mathrm{J}$ (1998) Isolation, characterization, molecular gene cloning, and sequencing of a novel phytase from Bacillus subtilis. Appl Environ Microbiol 64:2079-2085.

Khalid A, Tahir S, Arshad M and Zahir ZA (2004) Relative efficiency of rhizobacteria for auxin biosynthesis in rhizosphere and non-rhizosphere soils. Soil Res 42:921-926.

Khan MS, Zaidi A and Wani PA (2009) Role of phosphatesolubilizing microorganisms insustainable agriculture - A review. Agron Sustain Dev 27:29-43.

Kibblewhite MG, Ritz K and Swift MJ (2008) Soil health in agricultural systems. Philos Trans R Soc Lond B Biol Sci 363:685-701.

Kobayashi T and Nishizawa NK (2012) Iron uptake, translocation, and regulation in higher plants. Annu Rev Plant Biol 63:131-52.

Krewulak HD and Vogel HJ (2008) Structural biology of bacterial iron uptake. Biochim Biophys Acta 1778:1781-804.

Kumar V, Singh P, Jorquera MA, Sangwan P, Kumar P, Verma AK and Agrawal S (2013) Isolation of phytase-producing bacteria from Himalayan soils and their effect on growth and phosphorus uptake of Indian mustard (Brassica juncea). World J Microbiol Biotechnol 29:1361-1369.

Leigh JA and Coplin DL (1992) Exopolysaccharides in plantbacterial interactions. Annu Rev Microbiol 46:307-346.

Lemanceau P, Bauer P, Kraemer S and Briat JF (2009) Iron dynamics in the rhizosphere as a case study for analyzing interactions between soils, plants and microbes. Plant Soil 321:513-535.

Leveau JHJ and Lindow SE (2005) Utilization of the plant hormone indole-3-acetic acid for growth by Pseudomonas putida strain 1290. Appl Environ Microbiol 71:2365-2371.

Loaces I, Ferrando L and Scavino AF (2011) Dynamics, diversity and function of endophytic siderophore-producing bacteria in rice. Microb Ecol 61:606-618.

Long SR (2001) Genes and signals in the Rhizobium legume symbiosis. Plant Physiol 125:69-72.

Lynch JM and Bragg E (1985) Microorganisms and soil aggregate stability. In: Stewart BA (ed) Advances in Soil Science. Springer, New York, pp 133-171.

Lynch JM (1990) The rhizosphere. Wiley-Interscience, Chichester, $458 \mathrm{p}$.

Majumder B and Kuzyakov Y (2010) Effect of fertilization on decomposition of ${ }^{14} \mathrm{C}$ labelled plant residues and their incorporation into soil aggregates. Soil Tillage Res 109:94-102.

Martinez JL, Sanchez MB, Martinez-Solano L, Hernandez A, Garmendia L, Fajardo A and Alvarez-Ortega C (2009) Functional role of bacterial multidrug efflux pumps in microbial natural ecosystems. FEMS Microbiol Rev 33:430449. 
McLaughlin MJ, McBeath TM, Smernik R, Stacey SP, Ajiboye B and Guppy C (2011) The chemical nature of $P$ accumulation in agricultural soils-implications for fertilizer management and design: An Australian perspective. Plant Soil 349:69-87.

Meneses CH, Rouws LF, Simões-Araújo JL, Vidal MS and Baldani JI (2011) Exopolysaccharide production is required for biofilm formation and plant colonization by the nitrogenfixing endophyte Gluconacetobacter diazotrophicus. Mol Plant-Microbe Interact 24:1448-1458.

Miché L, Battistoni FJ, Gemmer S, Belghazi M and ReinholdHurek B (2006) Upregulation of jasmonate-inducible defense proteins and differential colonization of roots of Oryza sativa cultivars with the endophyte Azoarcus sp. Mol Plant-Microbe Interact 19:502-511.

Miller SH, Browne P, Prigent-Combaret C, Combes-Meynet E, Morrissey JP and O'Gara F (2010) Biochemical and genomic comparison of inorganic phosphate solubilization in Pseudomonas species. Environ Microbiol Rep 2:403-411.

Moat AG and Foster JW (1995) Nitrogen metabolism. In: Moat AG and Foster JW (eds) Microbial Physiology. Wiley-Liss, New York, pp. 436-461.

Monteiro RA, Schmidt MA, de Baura VA, Balsanelli E, Wassem R, Yates MG, Randi MAF, Pedrosa FO and de Souza EM (2008) Early colonization pattern of maize (Zea mays L. Poales, Poaceae) roots by Herbaspirillum seropedicae (Burkholderiales, Oxalobacteraceae). Genet Mol Biol 31:932-937.

Morel MA, Braña V and Castro-Sowinski S (2012) Legume crops, importance and use of bacterial inoculation to increase production. In: Plant Crop. Aakash Goyal (ed) Intech, Rijeka, pp. 217-240.

Mougel C, Offre P, Ranjard L, Corberand T, Gamalero E, Robin C and Lemanceau P (2006) Dynamic of the genetic structure of bacterial and fungal communities at different developmental stages of Medicargo truncatula gaertn $\mathrm{cv}$ jemalong line J5. New Phytol 170:165-175.

Muthukumarasamy R, Cleenwerk I, Revathi G, Vadivelu M, Janssens D, Hoste B, Gum KU, Park KD, Son CY, Sa T, et al. (2005) Natural association of Gluconacetobacter diazotrophicus and diazotrophic Acetobacter peroxydans with wetland rice. Syst Appl Microbiol 28:277-286.

Neal AL, Ahmad S, Gordon-Weeks R and Ton J (2012) Benzoxazinoids in root exudates of maize attract Pseudomonas putida to the rhizosphere. PLoS One 7:e35498.

Neilands JB (1995) Siderophores: Structure and function of microbial iron transport compounds. J Biol Chem 270:2672326726.

Newton WE (2000) Nitrogen fixation in perspective. In: Pedrosa FO, Hungria M, Yates MG and Newton WE (eds) Nitrogen Fixation: From Molecules to Crop Productivity. Kluwer Academic Publishers, Dordrecht, pp 3-8.

Nicol D, Copaja SV, Wratten SD and Niemeyer HM (1992) A screen of worldwide wheat cultivars for hydroxamic acid levels and aphid antixenosis. Ann Appl Biol 121:11-18.

Njoloma J, Tanaka K, Shimizu T, Nishiguchi T, Zakria M, Akashi $\mathrm{R}$, Oota M and Akao S (2006) Infection and colonization of aseptically micropropagated sugarcane seedlings by nitrogen-fixing endophytic bacterium, Herbaspirillum sp. B501gfp1. Biol Fertil Soils 43:137-143.
Okon Y and Labandrera-Gonzalez CA (1994) Agronomic applications of Azospirillum: An evaluation of 20 years of worldwide field inoculation. Soil Biol Biochem 26:1591-1601.

Oliveira ALM, Urquiaga S, Döbereiner J and Baldani JI (2002) The effect of inoculating endophytic $\mathrm{N}_{2}$ fixing bacteria on micro propagated sugarcane plants. Plant Soil 2:205-215.

Onofre-Lemus J, Hernández-Lucas I, Girard L and CaballeroMellado J (2009) ACC (1-aminocyclopropane-1-carboxylate) deaminase activity, a widespread trait in Burkholderia species, and its growth-promoting effect on tomato plants. App Environ Microbiol 75:6581-6590.

Pedrosa FO Monteiro RA, Wassem R, Cruz LM, Ayub RA, Colauto NB, Fernandez MA, Fungaro MHP, Grisard EG, Hungria M, et al. (2011) Genome of Herbaspirillum seropedicae strain SmR1, a specialized diazotrophic endophyte of tropical grasses. PLoS Genet 7:e1002064.

Prinsen E, Costacurta A, Michiels K, Vanderleyden J and Onckelen H (1993) Azospirillum brasilense indole-3-acetic acid biosynthesis: Evidence for a non-tryptophan dependent pathway. Mol Plant-Microbe Interact 6:609-615.

Pulleman M, Creamer R, Hamer U, Helder J, Pelosi C, Peres G and Rutgers M (2012) Soil biodiversity, biological indicators and soil ecosystem services-an overview of European approaches. Curr Opin Environ Sustain 4:529-538.

Qin L, Jiang H, Tian J, Zhao J and Liao H (2011) Rhizobia enhance acquisition of phosphorus from different sources by soybean plants. Plant Soil 349:25-36.

Ramachandran VK, East AK, Karunakaran R, Downie JA and Poole PS (2011) Adaptation of Rhizobium leguminosarum to pea, alfalfa and sugar beet rhizospheres investigated by comparative transcriptomics. Genome Biol 12:R106.

Remans R, Beebe S, Blair M, Manrique G, Tovar E, Rao I, Croonenborghs A, Torres-Gutierrez R, El-Howeity M, Michiels J, et al. (2008) Physiological and genetic analysis of root responsiveness to auxin-producing plant growthpromoting bacteria in common bean (Phaseolus vulgaris L.). Plant Soil 302:149-161.

Richardson AE and Simpson RJ (2011) Soil microorganisms mediating phosphorus availability. Plant Physiol 156:989-996.

Robinson CJ, Bohannan BJ and Young VB (2010) From structure to function: The ecology of host-associated microbial communities. Microbiol Mol Biol Rev 74:453-476.

Rocha FR, Papini-Terzi FS, Nishiyama Jr MY, Vêncio RZN, Vicentini R, Duarte RDC, de Rosa Jr VE, Vinagre F, Barsalobres C, Medeiros AM, et al. (2007) Signal transduction-related responses to phytohormones and environmental challenges in sugarcane. BMC Genomics 8:e71.

Rodríguez H and Fraga R (1999) Phosphate solubilizing bacteria and their role in plant growth promotion. Biotechnol Adv 17:319-339.

Rodríguez H, Fraga R, Gonzalez T and Bashan Y (2006) Genetics of phosphate solubilization and its potential applications for improving plant growth-promoting bacteria. Plant Soil 287:15-21.

Rodriguez-Navarro DN, Dardanelli MS and Ruiz-Sainz JE (2007) Attachment of bacteria to the roots of higher plants. FEMS Microbiol Lett 272:127-136.

Rosenthal GA (1972) Investigations of canavanine biochemistry in the jack bean plant, Canavalia ensiformis (L) DC: II Canavanine biosynthesis in the developing plant. Plant Physiol 50:328-331. 
Rothballer M, Eckert B, Schmid M, Fekete A, Schloter M, Lehner A, Pollmann S and Hartmann A (2008) Endophytic root colonization of gramineous plants by Herbaspirillum frisingense. FEMS Microbiol Ecol 66:85-95.

Rovira AD (1965) Interactions between plant roots and soil micro-organisms. Annu Rev Microbiol 19:241-266.

Ruamps LS, Nunan N and Chenu C (2011) Microbial biogeography at the soil pore scale. Soil Biol Biochem 43:280-286.

Rudrappa T, Czymmek KJ, Paré PW and Bais HP (2008) Rootsecreted malic acid recruits beneficial soil bacteria. Plant Physiol 148:1547-1556.

Saleem M, Arshad M, Hussain S and Bhatti AS (2007) Perspective of plant growth promoting rhizobacteria (PGPR) containing $\mathrm{ACC}$ deaminase in stress agriculture. J Ind Microbiol Biotechnol 34:635-648.

Schenk ST, Stein E, Kogel KH and Schikora A (2012) Arabidopsis growth and defense are modulated by bacterial quorum sensing molecules. Plant Signal Behav 7:178-181.

Schmidt MW, Torn MS, Abiven S, Dittmar T, Guggenberger G, Janssens IA, Kleber M, Kögel-Knabner I, Lehmann J, Manning DAC, et al. (2011) Persistence of soil organic matter as an ecosystem property. Nature 47:49-56.

Sevilla M, Burris RH, Gunapala N and Kennedy C (2001) Comparison of benefit to sugarcane plant growth and ${ }^{15} \mathrm{~N}_{2}$ incorporation following inoculation of sterile plants with Acetobacter diazotrophicus wild-type and Nif mutant strains. Mol Plant-Microbe Interact 14:358:366.

Shade A, Peter H, Allison SD, Baho L, Berga M, Bürgmann H, Huber DH, Langenheder S, Lennon JT, Martiny JBH, et al. (2012) Fundamentals of microbial community resistance and resilience. Front Microbiol 3:1-19.

Shaharoona B, Arshad M and Zahir ZA (2006) Effect of plant growth promoting rhizobacteria containing ACC-deaminase on maize (Zea mays L.) growth under axenic conditions and on nodulation in mung bean (Vigna radiata L.). Lett Appl Microbiol 42:155-159.

Sharma SB, Sayyed RZ, Trivedi MH and Gobi TA (2013) Phosphate solubilizing microbes: Sustainable approach for managing phosphorus deficiency in agricultural soils. Springerplus 2:1-14.

Sharma SK, Ramesh A and Johri BN (2013) Isolation and characterization of plant growth promoting Bacillus amyloliquefaciens strain sks_bnj_1 and its influence on rhizosphere soil properties and nutrition of soybean (Glycine $\max$ L. Merrill). J Virol Microbiol 2013:1-19.

Shenoy VV, Kalagudi GM and Gurudatta BV (2001) Towards nitrogen autotrophic rice. Curr Sci 81:451-457.

Singh P, Kumar V and Agrawal S (2014) Evaluation of phytase producing bacteria for their plant growth promoting activities. Int J Microbiol 2014-1-7.

Shridhar BS (2012) RNitrogen fixing microorganisms. Int J Microbiol Res 3:46-52.

Six J, Paustian K, Elliott ET and Combrink C (2000) Soil structure and organic matter. I. Distribution of aggregate-size classes and aggregate-associated carbon. Soil Sci Soc Am J 64:681-689.

Souza R, Beneduzi A, Ambrosini A, Costa PB, Meyer J, Vargas LK, Schoenfeld R and Passaglia LMP (2013). The effect of plant growth-promoting rhizobacteria on the growth of rice (Oryza sativa L.) cropped in southern Brazilian fields. Plant Soil 366:585-603.
Souza R, Meyer J, Schoenfeld R, Costa PB and Passaglia LMP (2014) Characterization of plant growth-promoting bacteria associated with rice cropped in iron-stressed soils. Ann Microbiol 65:951-964.

Spaepen S, Vanderleyden J and Remans R (2007) Indole-3-acetic acid in microbial and microorganism-plant signaling. FEMS Microbiol Rev 31:425-448.

Spaepen S, Dobbelaere S, Croonenborghs A and Vanderleyden J (2008) Effects of Azospirillum brasilense indole-3-acetic acid production on inoculated wheat plants. Plant Soil 312:15-23.

Stein RJ, Duarte GL, Spohr MG, Lopes SIG and Fett JP (2009) Distinct physiological responses of two rice cultivars subjected to iron toxicity under field conditions. Ann Appl Biol 154:269-277.

Straub D, Yang H, Liu Y, Tsap T and Ludewig U (2013) Root ethylene signalling is involved in Miscanthus sinensis growth promotion by the bacterial endophyte Herbaspirillum frisingense GSF30T. J Exp Bot 64:4603-4615.

Sun Y, Cheng Z and Glick BR (2009) The presence of a 1-aminocyclopropane-1-carboxylate (ACC) deaminase deletion mutation alters the physiology of the endophytic plant growthpromoting bacterium Burkholderia phytofirmans PsJN. FEMS Microbiol Lett 296:131-136.

Szilagyi-Zecchin VJ, Ikeda AC, Hungria M, Adamoski D, KavaCordeiro V, Glienke C and Galli-Terasawa LV (2014) Identification and characterization of endophytic bacteria from corn (Zea mays L.) roots with biotechnological potential in agriculture. AMB Express 4:2-9.

Terakado-Tonooka J, Ohwaki Y, Yamakawa H, Tanaka F, Yoneyama T and Fujihara S (2008). Expresses nifH genes of endophytic bacteria detected in field-growth sweet potatoes (Ipomoea batata L.). Microbes Environl 23:89-93.

Thaweenut N, Hachisuka Y, Ando S, Yanagisawa S and Yoneyama T (2011). Two seasons' study on nifH gene expression and nitrogen fixation by diazotrophic endophytes in sugarcane (Saccharum spp. hybrids): Expression of nifH genes similar to those of rhizobia. Plant Soil 338:435-449.

Torres AR, Kaschuk G, Saridakis GP and Hungria M (2012) Genetic variability in Bradyrhizobium japonicum strains nodulating soybean Glycine max (L.) Merrill. World J Microbiol Biotechnol 28:1831-1835.

Tortora ML, Díaz-Ricci JC and Pedraza RO (2011) Azospirillum brasilense siderophores with antifungal activity against Colletotrichum acutatum. Arch Microbiol 193:275-286.

Upadhyay SK, Singh JS, Saxena AK and Singh DP (2012) Impact of PGPR inoculation on growth and antioxidant status of wheat under saline conditions. Plant Biol 14:605-611.

Valverde A, Burgos A, Fiscella T, Rivas R, Velázquez E, Rodríguez-Barrueco C, Cervantes E, Chamber M and Igual J-M (2006) Differential effects of coinoculations with Pseudomonas jessenii PS06 (a phosphate-solubilizing bacterium) and Mesorhizobium ciceri C-2/2 strains on the growth and seed yield of chickpea under greenhouse and field conditions. Plant Soil 287:43-50.

Vogel C, Babin D, Pronk GJ, Heister K, Smalla K and KögelKnabner I (2014) Establishment of macro-aggregates and organic matter turnover by microbial communities in longterm incubated artificial soils. Soil Biol Biochem 79:57-67. 
Vos M, Wolf AB, Jennings SJ and Kowalchuk GA (2013) Micro-scale determinants of bacterial diversity in soil. FEMS Microbiol Rev 37:936-954.

Walker V, Bertrand C, Bellvert F, Moënne-Loccoz Y, Bally R and Comte G (2011a) Host plant secondary metabolite profiling shows a complex, strain-dependent response of maize to plant growth-promoting rhizobacteria of the genus Azospirillum. New Phytol 189:494-506.

Walker V, Couillerot O, Von Felten A, Bellvert F, Jansa J, Maurhofer M, Bally R, Moënne-Loccoz Y and Comte G (2011b) Variation of secondary metabolite levels in maize seedling roots induced by inoculation with Azospirillum, Pseudomonas and Glomus consortium under field conditions. Plant Soil 356:151-163.

Wartiainen I, Eriksson T, Zheng W and Rasmussen U (2008) Variation in the active diazotrophic community in rice paddy-nifH PCR-DGGE analysis of rhizosphere and bulk soil. Appl Soil Ecol 39:65-75.

Wasternack C (2007) Jasmonates: An update on biosynthesis, signal transduction and action in plant stress response, growth and development. Ann Bot 100:681-697.

Willems A (2007) The taxonomy of rhizobia: An overview. In: Velazquez E and Rodryguez-Barrueco C (eds) First International Meeting on Microbial Phosphate Solubilization. Springer, Berlin, pp 3-14.

Wolf AB, Vos M, de Boer W and Kowalchuk GA (2013) Impact of matric potential and pore size distribution on growth dynamics of filamentous and non-filamentous soil bacteria. PLoS One 8:e83661.
Yoon SJ, Choi YJ, Min HK, Cho KK, Kim JW, Lee SC and Jung YH (1996) Isolation and identification of phytase producing bacterium, Enterobacter sp. 4, and enzymatic properties of phytase enzyme. Enzyme Microb Tech 18:449-454.

You M, Nishiguchi T, Saito A, Isawa T, Mitsui H and Minamisawa K (2005) Expression of the nifH gene of a Herbaspirillum endophyte in wild rice species: Daily rhythm during the light-dark cycle. Appl Environ Microbiol 71:8183-8190.

Young IM and Ritz K (1999) Tillage, habitat space and function of soil microbes. Soil Tillage Re 53:201-213.

Zahir ZA, Munir A, Asghar HN, Shaharoona B and Arshad M (2008) Effectiveness of rhizobacteria containing ACC deaminase for growth promotion of peas (Pisum sativum) under drought conditions. J Microbiol Biotechnol 18:958963.

Zehr JP, Jenkins BD, Short SM and Steward GF (2003) Nitrogenase gene diversity and microbial community structure: A cross-system comparison. Environ Microbiol 5:539-554.

Zhang H (1994) Organic matter incorporation affects mechanical properties of soil aggregates. Soil Tillage Res 31:263-275.

Zhang J, Boone L, Kocz R, Zhang C, Binns AN and Lynn DG (2000) At the maize/Agrobacterium interface: Natural factors limiting host transformation. Chem Biol 7:611-621.

Zhang S, Li Q, Lü Y, Zhang X and Liang W (2013) Contributions of soil biota to $\mathrm{C}$ sequestration varied with aggregate fractions under different tillage systems. Soil Biol Biochem 6

$$
\text { Associate Editor: Célia Maria de Almeida Soares }
$$

License information: This is an open-access article distributed under the terms of the Creative Commons Attribution License (type CC-BY), which permits unrestricted use, distribution and reproduction in any medium, provided the original article is properly cited. 